\title{
Molecular cloning and seasonal expression of oyster glycogen phosphorylase and glycogen synthase genes
}

\author{
H. Bacca ${ }^{a}$, A. Huvet ${ }^{a,}$, C. Fabioux ${ }^{a}$, J.-Y. Daniel $^{a}$, M. Delaporte ${ }^{a}$, \\ S. Pouvreau ${ }^{\mathrm{a}}$, A. Van Wormhoudt ${ }^{\mathrm{b}}$ and J. Moal ${ }^{\mathrm{a}}$
}

\begin{abstract}
a : UMR Physiologie et Ecophysiologie des Mollusques Marins, Ifremer, Centre de Brest, B.P. 70, 29280
Plouzané, France

b : UMR 5178, Station de Biologie Marine du Muséum National d'Histoire Naturelle, BP225, 29900 Concarneau, France
\end{abstract}

*: Corresponding author: Tel.: +332982246 93; fax: +33298224653

\begin{abstract}
:
To investigate the control at the mRNA level of glycogen metabolism in the cupped oyster Crassostrea gigas, we report in the present paper the cloning and characterization of glycogen phosphorylase and synthase cDNAs ( $\mathrm{Cg}-\mathrm{GPH}$ and $\mathrm{Cg}$-GYS, respectively, transcripts of main enzymes for glycogen use and storage), and their first expression profiles depending on oyster tissues and seasons. A strong expression of both genes was observed in the labial palps and the gonad in accordance with specific cells located in both tissues and ability to store glucose. $\mathrm{Cg}-\mathrm{GPH}$ expression was also found mainly in muscle suggesting ability to use glycogen as readily available glucose to supply its activity. For seasonal examinations, expression of $C g-G Y S$ and $C g-G P H$ genes appeared to be regulated according to variation in glycogen content. Relative levels of $C g$-GYS transcripts appeared highest in October corresponding to glycogen storage and resting period. Relative levels of $\mathrm{Cg}-\mathrm{GPH}$ transcripts were highest in May corresponding to mobilization of glycogen needed for germ cell maturation. Expression of both genes would likely be driven by the oyster's reproductive cycle, reflecting the central role of glycogen in energy storage and gametogenic development in C. gigas. Both genes are useful molecular markers in the regulation of glycogen metabolism and reproduction in C. gigas but enzymatic regulation of glycogen phosphorylase and synthase remains to be elucidated.
\end{abstract}

Keywords: Bivalve; Crassostrea gigas; Energy; Gene; Expression; Glycogen; Oyster; Regulation; Reproduction 


\section{Introduction}

Glucose constitutes an important nutrient which is provided either from the diet, from glycogen storage or from amino acids and lactate via gluconeogenesis (Felber and Golay, 1995). In marine bivalves, glycogen is the major source of glucose reserves stored in specific vesicular cells (Berthelin et al., 2000b) and is known to play a central role in providing energy for maintenance and gametogenic development of bivalves (Bayne et al., 1982; Gabbott and Whittle, 1986; Ruiz et al., 1992; Mathieu and Lubet, 1993). A seasonal cycle of storage and mobilization of energetic reserves, especially glycogen but also stored lipids, was previously correlated with the annual reproductive cycle of bivalves (Berthelin et al., 2000b). Indeed, glycogen content was positively associated with fecundity in oysters and negatively associated with gametogenic rate (Deslous-Paoli et al., 1981). Glycogen content is also positively linked with survival: survival of oysters during summer (Perdue et al., 1981; Berthelin et al., 2000a) or survival of crustacea following anoxic stress (Hervant and Mathieu, 1995; Oliveira and da Silva, 2000).

Glycogen is a polysaccharide with $\alpha(1-4)$ glucosidic bonds plus secondary $\alpha(1-6)$ glucosidic branches spaced every 7 to 20 residues along the principal chain. In vertebrates, glycogen is mainly found in the liver and in skeletal muscle where it constitutes stores of readily available glucose to supply tissues. Its major role to sustain and regulate available glucose is wellknown and changes in glycogen metabolism are associated with important human diseases such as hypoglycemia and myopathy (Blass et al., 1988).

The glycogen pathway is directly under the control of two unidirectional enzymes: glycogen phosphorylase (glycogenolysis) and glycogen synthase (glycogenesis). Glycogen phosphorylase is a homodimeric or tetrameric enzyme that removes glucose residues from $\alpha(1-4)$ linkages within glycogen molecules to produce glucose-1-phosphate (Childress and Sacktor, 1970; Morishima and Sakurai, 1985; San Juan et al, 1991; for review see King, 
1996). Covalent modifications by phosphorylation (by a phosphorylase kinase) lead to regulation of its activity. Phosphorylation of phosphorylase-b to phosphorylase-a greatly enhances its activity towards glycogen breakdown as observed in immediate adaptive response of mussels to thermal stress (San Juan et al., 1993). The enzyme is activated by AMP and is inhibited by a variety of allosteric effectors that include glucose, ATP (Kasvinsky et al., 1978; San Juan et al., 1998). Glycogen synthase is a tetrameric enzyme that catalyses the transfer of glucose molecule from UDP-glucose to a terminal branch of glycogen molecule (Cohen, 1986). The activity of glycogen synthase is inversely regulated by phosphorylation of serine residues. The unphosphorylated and most active form is synthase-a while the phosphorylated glucose-6-phosphate-dependent form is synthase-b. Both synthase forms were reported in molluscs as I and D respectively, in Mytilus edulis (Gabbott and Whittle, 1986) and in Crassostrea virginica (Swift et al., 1988). This enzymatic regulation controls part of glycogen metabolism, especially short-term regulation. In addition, long-term regulation of carbohydrate metabolism can be influenced by expression of genes encoding enzymes implicated in the glucose pathway (Nordlie et al., 1999), such as genes encoding glycogen synthase and glycogen phosphorylase (Towle, 1995; Vali et al., 2000). In bivalve molluscs and especially in the oyster, long term regulation of glycogen metabolism has never been studied yet. Long-term regulation is under the control of exogenous or endogenous factors especially insulin and epinephrine (Reynet et al, 1996). In Mytilus edulis, distinct neuroendocrine factors were reported to stimulate the start of both gametogenesis and glycogen breakdown and feedback from gonad maturation to storage metabolism was suspected (Mathieu et al., 1991). In adult oysters, seasonal variation in glycogen storage correlated with the annual reproductive cycle were not totally explained by changes in the concentration of extracellular glucose (Mathieu and Lubet, 1993; Berthelin et al., 2000a) suggesting the role of some other factors (neuroendocrine, external factors). 
To contribute to our knowledge of glucose storage processes in oysters and to develop specific molecular markers of glycogen metabolism, we report in the present paper the cloning and characterization of glycogen phosphorylase and glycogen synthase cDNAs and the assay by real time PCR analysis of their expression in different oyster tissues and seasons. The use of these genes in understanding relationships between glycogen metabolism and

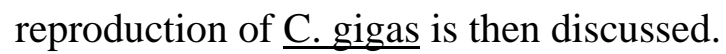

\section{Material and Methods}

\subsection{Biological material}

In order to take into account the influence of environmental effects and age of oyster, experimental cross was performed at the hatchery at the IFREMER Laboratory in La Tremblade (France) from 30 wild oysters collected in the Marennes-Oléron Bay (Dégremont, 2003). These oysters were then cultured at the IFREMER station in Bouin (France). Oneyear-old cupped oysters (mean total weight $=17 \pm 5 \mathrm{~g}$ ), of same age and same environmental background, were conditioned in experimental raceways, at the IFREMER Laboratory in Argenton (France), from February 2002 to February 2003 in 300-L raceways with $20 \mu \mathrm{m}$ filtered running seawater. Oysters were fed on a mixed diet of three micro-algal species (33\%

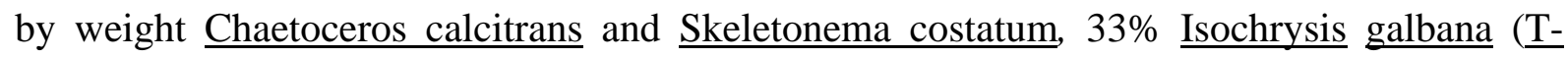
$\underline{\text { ISO), }} 33 \%$ Tetraselmis chui) at a daily ration equal to $8 \%$ dry weight algae/dry weight oyster. Temperature and photoperiod were regulated to follow the mean natural cycles recorded in Marennes-Oléron Bay during the last ten years (Soletchnik et al., 1998).

For cloning cDNAs, oysters were randomly collected from raceways in March and November 2002 and immediately dissected. Collected tissues (labial palps, gonad) were lysed in RNA extraction buffer (Chomczynski and Sacchi, 1987). 
For gene expression analysis, 15 oysters were randomly collected at 8 different times (March 2002, May, June, July, August, October, December and January 2003). Six tissue samples (labial palps, mantle, gonad, digestive gland, muscle and gills) were immediately dissected from each oyster. Collected tissues were lysed in RNA extraction buffer (Chomczynski and Sacchi, 1987).

For biochemical analysis, 3 pools of 5 animals were sampled at the same time as samples were taken for gene expression analysis and were frozen in liquid nitrogen and then wholly ground with a Dangoumeau homogeniser at $-180^{\circ} \mathrm{C}$.

\subsection{Total RNA extraction and cDNA synthesis}

Total RNA was isolated using the procedure of Chomczynski and Sacchi (1987), then treated

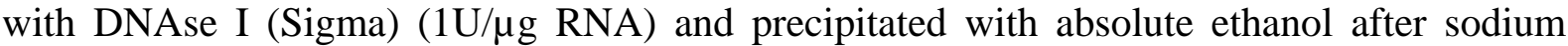
acetate (3M, pH 5.2) treatment. RNA concentrations were measured at $260 \mathrm{~nm}$ using the conversion factor $1 \mathrm{OD}=40 \mu \mathrm{g} / \mathrm{ml}$ RNA.

Samples of polyadenylated RNA were reverse-transcribed from $1 \mu$ g of total RNA denatured for 10 minutes at $70^{\circ} \mathrm{C}$. Reactions were carried out in a total volume of $25 \mu \mathrm{l}$ and the concentrations of the reaction components were as follows: 1X M-MLV Reverse Transcriptase buffer, 0.2 mM dNTPs, 4 mM DTT, $0.5 \mu g$ oligo(dT) primer, 25 U ribonuclease inhibitor and 50 U M-MLV Reverse Transcriptase. Reverse transcription was carried out for 10 min at $25^{\circ} \mathrm{C}, 20 \mathrm{~min}$ at $42^{\circ} \mathrm{C}$ and then 5 min at $94^{\circ} \mathrm{C}$.

\subsection{PCR, cloning and sequencing}

Degenerated PCR primers, forward primer GPF (5'-GCN GCN TGY TTY YTN GAY WSN ATG GC-3’), reverse primer GPR (5'-AAV AWR TTR TCR TTN GGR TAN ARN AC-3'), and forward primer GSF (5'-GAR TTY CAR AAY YTN CAY GC-3'), reverse primer GSR 
(5’-GCN GGN GTR TAN CCC CAN GG-3'), were designed based on conserved glycogen phosphorylase and synthase protein sequences, respectively, from human (Genbank Accession $\mathrm{N}^{\circ}$ : $\underline{\text { P06737 }}, \underline{\text { P11217 }}$ and $\underline{\text { P11216 }}$ for glycogen phosphorylase; $\underline{\text { NP_068776 }}$ and

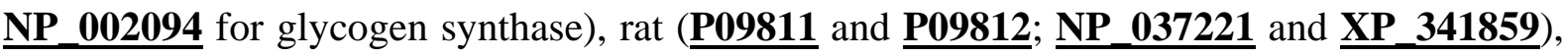
Drosophila melanogaster (Q9XTL9; $\underline{\text { Q9VFC8) }}$ ) and Caenorhabditis elegans (Q9N5U1; Q9U2D9). Polymerase chain reaction (PCR) was performed in a total volume of $25 \mu \mathrm{l}$ with $1 \mu \mathrm{g}$ of cDNAs, $1 \mu \mathrm{M}$ of each primers, $1 \mathrm{X}$ Taq buffer, $0.25 \mathrm{mM}$ dNTPs, $1.5 \mathrm{mM} \mathrm{MgCl} 2$ and $0.5 \mathrm{U}$ Taq polymerase (Qbiogene). Amplification was performed for 35 cycles at $94^{\circ} \mathrm{C}$ for 30 sec, $47^{\circ} \mathrm{C}$ for $1 \mathrm{~min}, 72^{\circ} \mathrm{C}$ for $2 \mathrm{~min} 30 \mathrm{sec}$ and a final extension step at $72^{\circ} \mathrm{C}$ for $5 \mathrm{~min}$. The PCR products were run on 1\% agarose gels with TAE buffer in $1 \mathrm{X}$ TAE buffer (Tris, acetic acid, and 0.5 M EDTA pH8) followed by staining with ethidium bromide. PCR products of expected size were gel-extracted (QIAquick gel extraction kit, Qiagen), cloned with a TOPOTA cloning kit (Invitrogen) and then sequenced (Qbiogene).

5' and 3' ends of the partial glycogen phosphorylase transcripts were isolated from cDNA using gene-specific primers with the Smart Race cDNA Amplification Kit (BD Biosciences). Reactions were performed for each 5' (reverse primer: 5'-CAG GTT CCT CAA CCT GCC AAC CAT C-3') and 3' ends (forward primer: 5'-TAC CGT GTC TCG CTG GCT GAG AAG A-3'). For the partial glycogen synthase transcript, a cDNA library constructed in $\lambda-$ ZAP II from C. gigas mantle-edge mRNA was screened as described by Huvet et al. (2004) using specific nested primers for each 5' (reverse primers: 5'-ACT CAT ATC TCC CAG CCG TGA-3’; 5’-TGT CTT ATC CAG ATC AAA GTC-3’ and 5’-GGC GTG AGT CGT GAA GAT GG-3') and 3' ends (forward primers: 5'-TGG CCT TGA CTA CGA GGA CTT 3' and 5'-GGG CTG TCA CCT TGG GGT GT-3'). PCR products were electrophorezed as described above and fragments of largest size were gel-extracted, subcloned into pCR 2.1® TOPO plasmid and sequenced as described above. 


\subsection{Phylogenetic analysis}

Phylogenetic analyses were carried out using a range of glycogen phosphorylase and synthase protein sequences from vertebrates and invertebrates. For most of vertebrates, the three characterised gene sequences (liver, muscle and brain forms) were included in the analysis. The sequences were aligned using CLUSTAL W (Thompson et al., 1994). An unrooted distance base phylogenetic tree was constructed in PHYLIP (Felsenstein, 1993) using the unweight pair group method with arithmetic mean (UPGMA). One thousand bootstrap trials were run using the Seqboot program from the PHYLIP package.

\subsection{Relative quantification of gene expression}

The presence of glycogen phosphorylase and glycogen synthase mRNA was investigated using real time PCR analysis. The detection technique for newly synthetised PCR products used SYBR Green I fluorescence dye (Morisson et al., 1998). Specific primers were designed with the assistance of primer 3 software (http://www-genome.wi.mit.edu/cgibin/primer/primer3_www.cgi) from glycogen synthase mRNA sequence (forward primer GSaF: 5'-GAC GCC AAC GAC CAA ATC-3'; reverse primer GSbR: 5'-TTC AGG AAC TCG GGG TGA-3') and glycogen phosphorylase mRNA sequence (forward primer GPfR: 5’-AGA CGG TCC CCG ATG ATT-3'; reverse primer GPeF: 5'-GGC AGC TCC TGG CTA TCA-3'). Amplifications of actin and elongation factor I cDNA were performed in order to confirm the steady-state level of expression of housekeeping genes allowing an internal control for gene expression. Actin and elongation factor I primers were those used by Huvet et al. (2003) and Fabioux et al. (2004b), respectively.

The real time PCR amplifications were carried out in triplicates in a total volume of $15 \mu \mathrm{l}$ with 1X SYBR ${ }^{\circledR}$ Green Master Mix (Qiagen), $10 \mathrm{nM}$ of fluorescein, $0.33 \mu \mathrm{M}$ each of forward and 
reverse primers and $5 \mu \mathrm{l}$ of the 1:5 diluted cDNA using iCycler iQ thermocycler (Biorad). After Taq Polymerase activation at $95^{\circ} \mathrm{C}$ for $15 \mathrm{~min}$, amplification was performed for 45 cycles at $95^{\circ} \mathrm{C}$ for $30 \mathrm{sec}$, at $60^{\circ} \mathrm{C}$ for 1 min with a single fluorescence measurement, and a final melting curve program by decreasing $0.5^{\circ} \mathrm{C}$ each 10 seconds from $95^{\circ} \mathrm{C}$ to $55^{\circ} \mathrm{C}$. Each run included a positive cDNA control (one sample of the present experiment analyzed in each amplification plate), negative controls (each total RNA sample with DNAse I treatment) and blank controls (water) analyzed for each primer pairs.

For gene expression calculation, the threshold value $(\mathrm{Ct})$ was determined for each target as the number of cycles at which the fluorescence rises appreciably above the background fluorescence. PCR efficiency (E) was determined for each primer pairs by determining the slope of standard curves obtained from serial dilution analysis of cDNA. The individual real time PCR efficiencies $(\mathrm{E})$ for target or reference gene were calculated according to: $\mathrm{E}=10^{(-}$ 1/slope) . When efficiencies are equal, the ratio becomes: $\mathrm{R}=2^{- \text {(CP target }-\mathrm{CP} \text { reference) }}$. The relative expression ratio $(\mathrm{R})$ of a target gene (glycogen synthase, glycogen phosphorylase) was calculated based on the $\mathrm{Ct}$ deviation of this target gene versus the reference gene, corresponding to the copy number of the target gene relative to the copy number of the reference gene.

\subsection{Glycogen content analysis}

Glycogen was determined through the enzymatic Keppler and Decker’s adapted method (1974). Samples (0.25g wet weight) were first homogenised in sodium citrate $0.1 \mathrm{M}$, pH 5.0. Glycogen was hydrolysed $2 \mathrm{~h}$ at $33^{\circ} \mathrm{C}$ with $3 \mathrm{U}$ amyloglucosidase (EC 3.2.1.3). Cellular fragments were removed by centrifugation $30 \mathrm{~min}$, at $4^{\circ} \mathrm{C}$. Glucose RTU® procedure was used to determinate glucose concentration. Glycogen concentration (mg glycogen/g Wet 
Weight) corresponds to the difference between the glucose concentration of the amyloglucosidase treated and non-treated samples, both being analyzed in duplicates.

\subsection{Statistical analysis}

Comparisons of levels of transcripts between different tissues or seasons were performed by median comparisons procedure using Kruskall Wallis test with STATGRAPHICS 5.0 software. Multiple comparisons were made with t-distribution test at the $5 \%$ level using UNISTAT 5.5 software.

\section{Results}

3.1 Isolation of the glycogen phosphorylase and glycogen synthase cDNAs from C. gigas For glycogen phosphorylase, a fragment of expected size was amplified from labial palps sampled in March with degenerated primers GPF and GPR. The 5' and 3' ends were obtained by RACE-PCR. The total isolated glycogen phosphorylase sequence of 3018 bp (Genbank accession number $\underline{\mathbf{A Y 4 9 6 0 6 5}}$ ) comprised a 5' untranslated region of $50 \mathrm{bp}$, an open reading frame of $2569 \mathrm{bp}$, a stop codon (TGA), and a 3' untranslated region of $399 \mathrm{bp}$. The deduced amino acid sequence is 855 aa long (Figure 1). It contains the phosphorylase pyridoxalphosphate attachment site (consensus: E-A-[SC]-G-x-[GS]-x-M-K-x(2)-[LM]-N), six Nglycosylation sites and twelve putative protein kinase phosphorylation sites or which one is cAMP- and cGMP-dependent, determined by homology. The amino acid sequence was $68 \%$ similar to that of vertebrates (Gallus gallus, Ovis aries, Oryctolagus cuniculus, Rattus $\underline{\text { norvegicus, Mus musculus, }} \underline{\text { Homo sapiens) }}$ whatever the tissue source (liver, muscle and brain form) and 68\% and 66\% similar to those of Drosophila melanogaster and Caenorhabditis elegans, respectively. Analysis of the phylogenetic relationships between glycogen phosphorylase enzymes showed several distinct clusters corresponding to Protozoa (Giardia 
intestinalis, Dictyostelium discoideum), Protostomia with Ecdysozoa (C. elegans, D. $\underline{\text { melanogaster }}$ ) and Lophotrochozoa (․ gigas) and to Deuterostomia based on three categories corresponding to liver, muscle and brain forms isolated in species (Figure 2).

For glycogen synthase, a fragment of expected size was amplified from labial palps sampled in November using degenerated primers GSF and GSR. The 5' and 3' ends were obtained by PCR using a C. gigas mantle-edge cDNA library as template. The total isolated glycogen synthase sequence was 2408 bp long corresponding to a deduced sequence of 695 aa (Genbank accession number $\underline{\mathbf{A Y 4 9 6 0 6 4}}$ ). It comprised a 5' untranslated region of $34 \mathrm{bp}$, an open reading frame of 2085 bp, a stop codon (TGA), and a 3’ untranslated region of 286 bp (Figure 1). It contains four N-glycosylation sites, nine putative protein kinase phosphorylation sites or which one is cAMP- and cGMP-dependent and one amidation site, determined by homology. The amino acid sequence was 53\% similar to that of vertebrates (Gallus gallus,

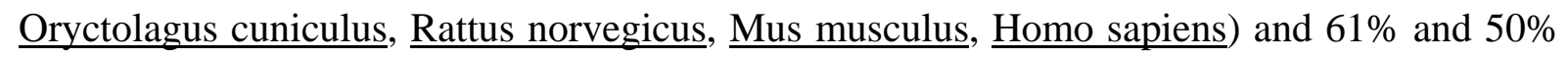

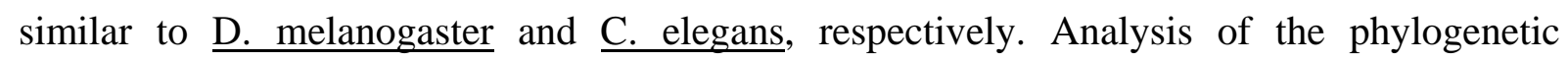
relationships between glycogen synthase enzymes showed three distinct clusters corresponding to Protozoa ( $\underline{\text { Giardia lamblia) }}$ ) and Protostomia (․ elegans, D. melanogaster

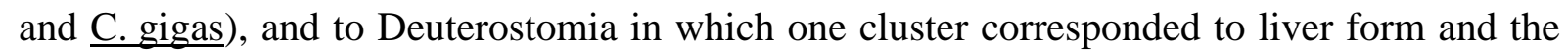
other one to muscle and brain forms (Figure 2).

\subsection{Tissue specific expression of glycogen synthase and phosphorylase genes}

Over an annual period, no significant differences in Ct values (related to $1 \mu$ g total RNA) were

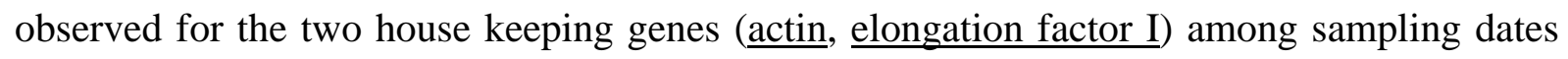
(Kruskall Wallis test: $\mathrm{P}=0.86$ and 0.2 for elongation factor I and $\underline{\text { actin}}$, respectively) but results of elongation factor I appeared more stable over the period (coefficient of variation =

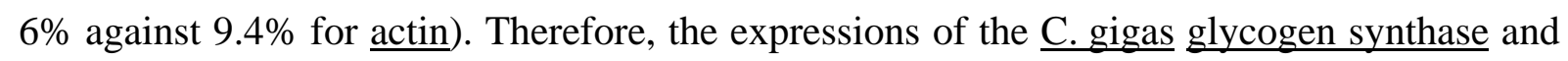


phosphorylase genes were expressed relative to the expression of the $\underline{C \text {. gigas }}$ elongation factor I gene, and analysed in various tissues by real time PCR in October and in May. Both genes were expressed, relative to elongation factor I, at different levels depending on the tissues (Figure 3). For glycogen synthase, two distinct groups were statistically evident: during October, transcripts were mainly found in gonad $\left(\mathrm{R}_{\mathrm{GS}}=0.20 \pm 0.13\right)$ and labial palps $\left(\mathrm{R}_{\mathrm{GS}}=0.11 \pm 0.04\right)$ whereas they ranged from 4.5 to 12 times less in muscle, mantle, gills and digestive gland. For glycogen phosphorylase, level of transcripts, relative to elongation factor

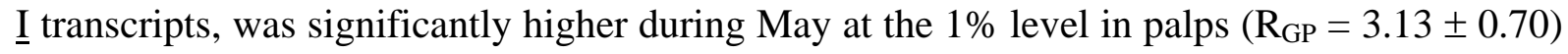
and muscle $\left(\mathrm{R}_{\mathrm{GP}}=2.42 \pm 0.81\right)$ than those observed in other tissues.

\subsection{Seasonal expression of glycogen synthase and phosphorylase genes}

During the experimental conditioning of C. gigas from March 2002 to January 2003, glycogen content showed a strong decrease from March (mean value $=23.41 \pm 3.32 \mathrm{mg}$ glycogen/g WW; Figure 4) to July where the minimal value was observed (mean value $=6.10$ $\pm 0.73 \mathrm{mg}$ glycogen/g WW). Thereafter, glycogen content increased until a maximal value in January (mean value $=34.65 \pm 5.89 \mathrm{mg}$ glycogen $/ \mathrm{g} \mathrm{WW}$ ).

Levels of both mRNAs were assayed by real time PCR in oyster labial palps and gonad during experimental conditioning. Both mRNA levels showed significant variation in the labial palps and gonad, depending on the month of sampling (Table 1). For both tissues, the level of glycogen synthase was highest in October $\left(\mathrm{R}_{\mathrm{GS}}\right.$ palps $=0.11 \pm 0.05$, $\mathrm{R}_{\mathrm{GS}}$ gonad $=0.20$ \pm 0.13 ) and not significantly different from values observed during March and May (only during May for labial palps). Its lowest level, close to zero, was observed in July ( $\mathrm{R}_{\mathrm{GS}}$ palps = $0.01 \pm 0.002, \mathrm{R}_{\mathrm{GS}}$ gonad $=0.002 \pm 0.001$; Figure 4 ), grouping statistically with values observed in the labial palps during January and in the gonad during August and January (Table 1). 
The relative level of the glycogen phosphorylase transcript observed in labial palps (Figure 4) was high from March to June with a value significantly higher in May compared to all other analysed months $\left(\mathrm{R}_{\mathrm{GP}}\right.$ palps $\left.=3.13 \pm 0.70\right)$. In other months, the relative level of glycogen phosphorylase transcript was low with a minimal value observed in July $\left(\mathrm{R}_{\mathrm{GP}}\right.$ palps $=0.28 \pm$ 0.16) that was not significantly different from values observed in August, October and January (Table 1). In the gonad, glycogen phosphorylase expression was maximum in March $\left(\mathrm{R}_{\mathrm{GP}}\right.$ gonad $\left.=1.07 \pm 0.35, \mathrm{P}<0.001\right)$ but low during the annual cycle. As observed in the labial palps, the minimum value for glycogen phosphorylase mRNA level was observed in July $\left(\mathrm{R}_{\mathrm{GP}}\right.$ gonad $\left.=0.05 \pm 0.04\right)$, grouping statistically with values observed during August and January.

Comparing both tissues, mRNA level of glycogen synthase and phosphorylase genes was significantly higher in the labial palps than in the gonad in May and January $(\mathrm{P}<0.05)$. In June, a significantly higher level of glycogen phosphorylase transcripts $(\mathrm{P}<0.05)$ was observed in the labial palps compared to the gonad. During other months, no significant differences in transcript levels between labial palps and gonad were detected.

Comparing both genes, level of glycogen phosphorylase transcripts appeared significantly higher than level of glycogen synthase transcripts whatever the analyzed sample (mean difference $=19.2 \pm 10.8 ; \mathrm{P}<0.05)$.

\section{Discussion}

\subsection{Glycogen synthase and glycogen phosphorylase genes of $\underline{\text { C. gigas }}$}

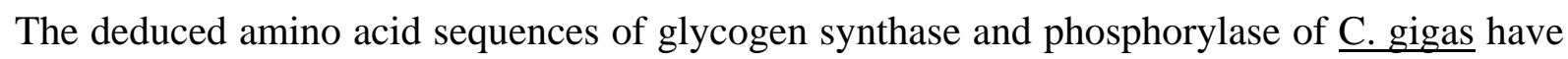
high homology with their invertebrate and vertebrate orthologues, suggesting a high degree of conservation through evolution. Phylogenetic analysis showed that $\underline{\text { C.gigas glycogen }}$ phosphorylase clustered with other Protostomia glycogen phosphorylase-related enzymes and 
possessed the phosphorylase pyridoxal-phosphate attachment site considered as a signature pattern of glycogen phosphorylases. In a same manner, phylogenetic tree showed that $\underline{\text { C. gigas }}$ glycogen synthase was closely related to Protostomia glycogen synthase-related enzymes (D.

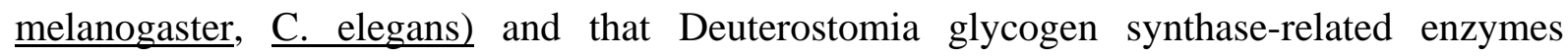
clustered into two groups depending on the tissue specific form (liver versus muscle and brain). These results suggest that our isolated sequences are oyster glycogen phosphorylase

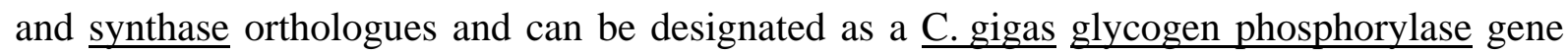

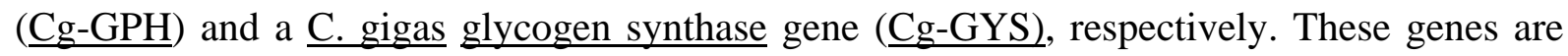
the first glycogen phosphorylase- and synthase-related genes isolated in the phylum Mollusca.

\subsection{Tissue expression of Cg-GYS and Cg-GPH}

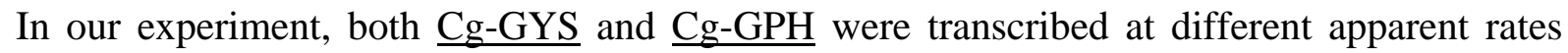
depending on the tissues. Preferential expression of $\underline{\text { Cg-GYS }}$ was observed in the labial palps and gonad in October. This is in accordance with the high level of glycogen content observed in these two tissues and their glycogen storage ability, previously characterised in oysters (Berthelin et al., 2000 a,b). Indeed, specific cells located in the labial palps and in the gonad were reported to be involved in glycogen storage (Berthelin et al., 2000b).

The level of $\underline{\text { Cg-GPH }}$ transcripts appeared high in labial palps and in muscle in May corresponding to glycogen degradation and mobilization of glucose and energy. In contrary to labial palps, muscle is not considered as a glycogen storage compartment in oysters since glycogen content does not exceed 5\% of its total biochemical content (Berthelin et al., 2000a). However, in many species, muscle is a place of active glycogenolysis to quickly provide ATP to muscular contractile activity and this activity is known to modulate expression of the glycogen phosphorylase gene in rat (Vali et al., 2000). In oyster, most tissues were capable of slight glycogen hydrolysis and/or glucose formation (Berthelin et al., 2000a,b) such as gills, 
mantle, digestive gland, where we observed a weak expression of both $\underline{\mathrm{Cg}-\mathrm{GYS}}$ and $\underline{\mathrm{Cg}-\mathrm{GPH}}$, and muscle where we observed a weak expression of Cg-GYS. Lastly, a weak mRNA level of Cg-GPH was observed in the gonad in May. According to Fabioux et al. (2004a), oysters were in maturation stage in May and their gonads were mainly constituted by germ cells. Only few specific storage cells, containing glycogen, remained in the gonad in May which could be at the origin of the low value of $\underline{\mathrm{Cg}-\mathrm{GPH}}$ transcripts.

\subsection{Seasonal expression of $\underline{\text { Cg-GYS }}$ and $\underline{\text { Gg-GPH }}$}

During our experimental conditioning, translatable mRNA for genes $\underline{\text { gg-GYS }}$ and $\underline{\text { Cg-GPH}}$ appeared to be seasonally regulated and correlated to glycogen content suggesting that the expression of genes encoding glycogen synthase and phosphorylase were strongly implicated in regulation of glycogen content as observed in mammals (Towle, 1995; Vali et al., 2000). Since a seasonal cycle of storage and mobilization of glycogen was previously correlated with the annual reproductive cycle of bivalves (Berthelin et al., 2000b), it can be postulated that the observed seasonal variations of $\underline{\mathrm{Cg}-\mathrm{GYS}}$ and $\underline{\mathrm{Cg}-\mathrm{GPH}}$ mRNA levels are closely linked to reproductive stages of oyster. According to histological data obtained with the same sampling (Fabioux et al., 2004a, in press), active gametogenesis began in March in our experiment. First gonadic tubules, composed by active mitotic germ cell, developed among a dense connective conjunctive tissue. Oysters entered maturation stage in April with differentiation of gonia into meiotic germ cell. In the same time, a switch from glycogen storage towards glycogen use seems to occur with a strong increase of $\underline{\mathrm{Cg}-\mathrm{GPH}}$ and a decrease of $\underline{\mathrm{Cg}-\mathrm{GYS}}$ and of glycogen content. In females, glycogen would be mobilized for vitellogenesis due to oocytes maturation with the accumulation of yolk and other nutritive substances (Dohmen, 1983) while in males, energy such as glycogen might be mobilized for active production of germ cells. In our conditioning, spawning occurred in July (Fabioux et al., 2004a). The end of 
reproduction led to very low levels of $\underline{\mathrm{Cg}-\mathrm{GYS}}$ and $\underline{\mathrm{Cg}-\mathrm{GPH}}$ transcripts observed in degenerating gonad during July and August. Thereafter, levels of translatable mRNA for $\underline{\mathrm{Cg}-}$ $\underline{\text { GYS }}$ and glycogen content began to increase, especially in October in labial palps and gonad. This increase coincided with a change from germinal to somatic development in the gonad. In October, reconstitution of a dense conjunctive tissue, mainly composed by specific storage cells, was observed (Fabioux et al., 2004a, in press).

In gonad, annual variation of its cellular composition (somatic storage cells vs germinal cells) could be at the origin of the variations observed of the mRNA levels of both genes mainly expressed by a single cell type (i.e. the specific storage cell). In labial palps which are only constituted by storage cells, the observed seasonal variations of $\underline{\text { Cg-GYS }}$ and $\underline{\text { Cg-GPH mRNA }}$ levels appeared linked to the reproductive cycle, both being putatively controlled by the same exogenous or endogenous factors. During experimental conditioning, the food ration was constant (a mixed diet of three micro-algal species equal to 8\% dry weight algae/ dry weight oyster per day). Therefore, food availability could not be the parameter that affected seasonal variation in glycogen content and expression of $\underline{\mathrm{Cg}-\mathrm{GYS}}$ and $\underline{\mathrm{Cg}-\mathrm{GPH}}$ genes. Temperature and photoperiod were the only environmental parameters that varied during our annual conditioning. These parameters were demonstrated to drive reproductive internal-clock of C. gigas (Fabioux et al., in press). The putative role of temperature or photoperiod in the regulation of glycogen pathways, especially for the expression of $\underline{\text { Cg-GYS }}$ and $\underline{\text { Cg-GPH}}$ genes, via the control of reproductive cycle is therefore questioned.

To conclude, expression of $\underline{\text { Cg-GYS }}$ and $\underline{\text { Cg-GPH }}$ appeared to be seasonally regulated in oysters and might be strongly implicated in the regulation of glycogen content. Nevertheless, regulation on catalytic parameters also exists (as observed in frog, Scapin and Giuseppe, 1994). Molecular and kinetic study of both enzymes are necessary to conclude that Cg-GYS and $\underline{\text { Gg-GPH }}$ are useful molecular markers to study regulation of glycogen metabolism and 


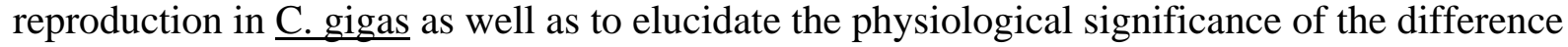
of expression between both genes. 


\section{Acknowledgements}

The authors are grateful to JF Samain, M Mathieu and JL Nicolas for their support during the course of this work. The authors are indebted to Chris Langdon (Oregon State University) for helpful comments on the manuscript and for his help for editing English language. We also acknowledge P Favrel for his technical advice. We thank all the staff of the Argenton, Bouin and La Tremblade stations for providing experimental oysters under controlled conditions. This work was supported by the MOREST national project funded by IFREMER and by the Région Basse-Normandie, Bretagne, Pays de la Loire and Poitou-Charentes and the conseil général du Calvados.

\section{References}

Bayne, B.L., Bubel, A., Gabbott, P.A., Livingstone, D.R., Lowe, D.M., Moore M.N., 1982. Glycogen utilisation and gametogenesis in Mytilus edulis (L.). Mar. Biol. Lett. 3, 89-105.

Berthelin, C., Kellner, K., Mathieu, M., 2000a. Storage metabolism in the Pacific oyster (Crassostrea gigas) in relation to summer mortalities and reproductive cycle (West Coast of France). Comp. Biochem. Physiol. 125B, 359-369.

Berthelin, C., Kellner, K., Mathieu, M., 2000b. Histological characterization and glucose incorporation into glycogen of the Pacific oyster Crassostrea gigas storage cells. Mar. Biotechnol. 2, 136-145.

Blass, J.P., Sheu, R.K., Cedarbaum, J.M., 1988. Energy metabolism in disorders of the nervous system. Rev. Neurol. 144, 543-63.

Childress, C.C., Sacktor, B., 1970. Regulation of glycogen metabolism in insect flight muscle. Purification and properties of phosphorylases in vitro and in vivo. J. Biol. Chem. 245, 29272936. 
Chomczynski, P., Sacchi, N., 1987. Single-step method of RNA isolation by acid guanidinium thiocyanate-phenol-chloroform extraction. Anal. Biochem. 162, 156-159.

Cohen, P., 1986. The enzymes. In Boyer, P.D. and Krebs, E.G. (eds), Academis Press, San Diego, CA, 17A, 461-497.

Dégremont, L., 2003. Genetic basis of summer mortality and relationship with growth in juvenile Pacific cupped oysters Crassostrea gigas. Thèse de l’Université de Caen, 322pp.

Deslous-Paoli, J.M., Héral, M., Berthome, J.P., Razet, D., Garnier, J., 1981. Natural reproduction of Crassostrea gigas Thunberg in Marennes-Oleron basin in 1979 and 1981: Biochemical and energetic aspects. Rev. Trav. Inst. Peches Marit. Nantes 45, 319-327.

Dohmen, M.R., 1983. Gametogenesis. In: The Mollusca. Development, Vol. 3, N.H. Verdonk, J.A.M. Van den Biggelaar and A.S. Tompa (eds.), Academic Press, New York, 1983, pp.1-48.

Fabioux, C., Pouvreau, S., Le Roux, F., Huvet, A., 2004a. The oyster Vasa-Like gene: a specific marker of the germ cell lineage in Crassostrea gigas. Biochem. Biophys. Res. Commun. 315, 897-904.

Fabioux, C., Huvet, A., Lelong, C., Robert, R., Pouvreau, S., Daniel, J.Y., Minguant, C., Le Pennec, M., 2004b. Oyster vasa-like gene as a marker of the germline cell development in Crassostrea gigas. Biochem. Biophys. Res. Commun. 320, 592-598.

Fabioux, C., Huvet, A., Le Souchu, P., Le Pennec, M., Pouvreau, S., 2005. Temperature and photoperiod drive Crassostrea gigas reproductive internal clock. Aquaculture, In press.

Felber, J.P., Golay, A., 1995. Regulation of nutrient metabolism and energy expenditure. Metabolism 44, 4-9.

Felsenstein, J., 1993. PHYLIP (Phylogenetic Inference Package, version 3.5c). Department of Genetics, SK, University of Washington, Seattle, WA. 
Gabbott, P.A., Whittle, M.A., 1986. Glycogen synthetase in the sea mussel Mytilus edulis (L.) -II: seasonal changes in the glycogen content and glycogen synthetase activity in the mantle tissue. Comp. Biochem. Physiol. 83B, 197-207.

Hervant, F., Mathieu J., 1995. Ventilatory and locomotory activities in anoxia and subsequent recovery of epigean and hypogean crustaceans. C. R. Acad. Sci. III, 318: 585-592.

Huvet, A., Dubois, S., Daniel, J.Y., Quéré, C., Prudence, M., Van Wormhoudt, A., Sellos, D., Samain, J.F., Moal, J., 2003. Tissue expression of two amylase genes in the Pacific oyster Crassostrea gigas. Effects of two different food rations. Aquaculture 228, 321-333.

Huvet, A., Herpin, A., Dégremont, L., Labreuche, Y., Samain, J.F., Cunningham, C., 2004. The identification of genes from the oyster Crassostrea gigas that are differentially expressed in progenies exhibiting opposed susceptibility to summer mortality. Gene, 343, 211-220.

Kasvinsky, P.J., Shechosky, S., Fletterick, R.J., 1978. Synergistic regulation of phosphorylase a by glucose and caffeine. J. Biol. Chem. 253, 9102-9106.

Keppler, D., Decker, K., 1974. Glycogen determination with amyloglucosidase. In: H. U. Bergmeyer, (ed.). Methods of Enzymatic Analysis. pp. 11-17.

King, M.W., 1996. Chapter 3: Biochemistry pp. 77-112 and Practice Test pp. 247-330; in Review for the USMLE Step I. 2nd edition: ed. Thomas K. Barton; Appleton and Lange, Stamford, CT.

Mathieu, M., Robbins, I., Lubet, P., 1991. The neuroendocrinology of Mytilus edulis. Aquaculture 94, 213-233.

Mathieu, M., Lubet, P., 1993. Storage tissue metabolism and reproduction in marine bivalvesa brief review. Invertebr. Reprod. Dev. 23, 123-129.

Morishima, I., Sakurai, S., 1985. Purification and characterization of glycogen phosphorylase b from fat body of the silkworm, Bombyx mori. Comp. Biochem. Physiol. 81B, 453-458. 
Morisson, T.B., Weiss, J.J., Wittwer, C.T., 1998. Quantification of low-copy transcripts by continous SYBR Green I monitoring during amplification. Biotechniques 24, 954-962.

Nordlie, R.C., Foster, J.D., Lange, A.J., 1999. Regulation of glucose production by the liver. Annu. Rev. Nutr. 19, 379-406.

Oliveira, G.T., da Silva, R.S., 2000. Hepatopancreas gluconeogenesis during hyposmotic stress in crabs Chasmagnathus granulata maintained on high-protein or carbohydrate-rich diets. Comp. Biochem. Physiol. 127B, 375-381.

Perdue, J.A., Beattie, J.H., Chew, K.K., 1981. Some relationships between gametogenetic cycle and summer mortality phenomenon in the Pacific oyster Crassostrea gigas in Washington State. J. Shellfish Res. 1, 9-16.

Reynet, C., Kahn, C.R., Loeken, M.R., 1996. Expression of the gene encoding glycogen phosphorylase is elevated in diabetic rat skeletal muscle and is regulated by insulin and cyclic AMP. Diabetologia 39, 183-189.

Ruiz, C., Martinez, D., Mosquera, G., Abad, M., Sanchez, J.L., 1992. Seasonal variations in condition, reproductive activity and biochemical composition of the flat oyster, Ostrea edulis, from San Cibran (Galicia, Spain). Mar. Biol. 112, 67-74.

Scapin, S. Di Giuseppe, G., 1994. Seasonal variations of glycogen synthase and phosphorylase activities in the liver of the frog Rana esculenta. Comp. Biochem. Physiol. 107B, 189-195.

San Juan Serrano, F., Fernandez Gonzalez, M., Sanchez Lopez, J.L., Garcia Martin, L.O., 1991. Purification and molecular properties of glycogen phosphorylase b from mantle tissue of mussel, Mytilus galloprovincialis. Comp. Biochem. Physiol. 98B, 33-39.

San Juan Serrano, F., Fernandez Gonzalez, M., Garcia Martin, L.O., 1993. Effect of temperature on glycogen phosphorylase activity of Mytilus galloprovincialis mantle tissue. 
Actas del IV congreso nacional de acuiculture, Centro de investigaciones marinas, Pontevedra (Spain), 425-430.

San Juan Serrano, F., Suarez Alonso, P., Blanco Lopez, S.L., Garcia Martin, L.O., 1998. Regulation of Mytilus galloprovincialis glycogen phosphorylase by glucose and glucose-6phosphate. J. Shellfish Res. 17, 159-163.

Soletchnik, P., Faury, N., Razet, D., Goulletquer, P., 1998. Hydrobiology of the MarennesOleron Bay. Seasonal indices and analysis of trends from 1978 to 1995 . Hydrobiologia 386, 1-3.

Swift, M.L., Akosah, K.O., Thomas, T.P., Humphrey, C.L., 1988. Characteristics of glycogen synthase activity in the digestive diverticula of the oyster, Crassostrea virginica Gmelin. J. Shellfish Res. 7, 177-178.

Thompson, J.D., Higgins, D.G., Gibson, T.J., 1994. CLUSTAL W: improving the sensitivity of progressive multiple sequence alignment through sequence weighting, positions-specific gap penalties and weight matrix choice. Nucleic Acids Research 22, 4673-4680.

Towle, H.C., 1995. Metabolic regulation of gene transcription in mammals. J. Biol. Chem. 270, 23235-8.

Vali, S., Carlsen, R., Pessah, I., Gorin, F., 2000. Role of the sarcoplasmic reticulum in regulating the activity-dependent expression of the glycogen phosphorylase gene in contractile skeletal muscle cells. J. Cell. Physiol. 185, 184-199. 


\section{Tables}

Table 1. Statistical comparison of ratio of glycogen synthase $\left(\mathrm{R}_{\mathrm{GS}}\right)$ and glycogen phosphorylase $\left(\mathrm{R}_{\mathrm{GP}}\right)$ transcripts relative to elongation factor I transcripts in labial palps and gonad during experimental conditioning from March to January.

\begin{tabular}{lll|ll}
\hline & $\mathrm{R}_{\mathrm{GS}}$ labial palps & $\mathrm{R}_{\mathrm{GP}}$ labial palps & $\mathrm{R}_{\mathrm{GS}}$ gonad & $\mathrm{R}_{\mathrm{GP}}$ gonad \\
\hline March & $0.10 \pm 0.04(\mathrm{~A})$ & $1.08 \pm 0.43(\mathrm{~B})$ & $0.09 \pm 0.06(\mathrm{~A})$ & $1.07 \pm 0.35(\mathrm{~A})$ \\
May & $0.07 \pm 0.04(\mathrm{AB})$ & $3.13 \pm 0.70(\mathrm{~A})$ & $0.02 \pm 0.01(\mathrm{BC})$ & $0.36 \pm 0.14(\mathrm{C})$ \\
June & $0.02 \pm 0.01(\mathrm{CD})$ & $0.72 \pm 0.26(\mathrm{~B})$ & $0.03 \pm 0.01(\mathrm{BC})$ & $0.46 \pm 0.21(\mathrm{BC})$ \\
July & $0.01 \pm 0.001(\mathrm{E})$ & $0.28 \pm 0.16(\mathrm{C})$ & $0.002 \pm 0.001(\mathrm{E})$ & $0.05 \pm 0.04(\mathrm{D})$ \\
Aug. & $0.03 \pm 0.02(\mathrm{BC})$ & $0.54 \pm 0.40(\mathrm{BC})$ & $0.01 \pm 0.01(\mathrm{CDE})$ & $0.21 \pm 0.20(\mathrm{CD})$ \\
Oct. & $0.11 \pm 0.04(\mathrm{~A})$ & $0.58 \pm 0.19(\mathrm{BC})$ & $0.20 \pm 0.13(\mathrm{~A})$ & $0.57 \pm 0.14(\mathrm{~B})$ \\
Dec. & $0.04 \pm 0.02(\mathrm{BCD})$ & $0.28 \pm 0.09(\mathrm{C})$ & $0.02 \pm 0.03(\mathrm{CD})$ & $0.37 \pm 0.09(\mathrm{BC})$ \\
Jan. & $0.01 \pm 0.002(\mathrm{DE})$ & $0.32 \pm 0.11(\mathrm{BC})$ & $0.004 \pm 0.002(\mathrm{DE})$ & $0.11 \pm 0.04(\mathrm{D})$ \\
K & 36.4 & 36.1 & 40.5 & 45 \\
P & $<0.001^{*}$ & $<0.001^{*}$ & $<0.001 *$ & $<0.001 *$
\end{tabular}

Analysis was performed using the Kruskall Wallis test. Test and probability values were given as $\mathrm{K}$ and $P$, respectively. Multiple comparisons were made using t-distribution test at the 5\% level and homogenous groups share similar alphabetic letters. 


\section{Caption to figures}

Figure 1. Nucleotidic sequence of the cDNA and deduced amino acid sequence of glycogen phosphorylase (above) and synthase (below) enzymes. Grey highlighted sequences are a putative N-glycosylation site (consensus: $\mathrm{N}-\{\mathrm{P}\}-[\mathrm{ST}]-\{\mathrm{P}\}$ ). A putative cAMP- and cGMPdependent protein kinase phosphorylation site ([RK](2)-X-[ST]) is underlined and putative protein kinase phosphorylation sites ([ST]-X-[RK]) are framed. For glycogen phosphorylase, the phosphorylase pyridoxal-phosphate attachment site is bold framed with a dotted line (consensus: E-A-[SC]-G-x-[GS]-x-M-K-x(2)-[LM]-N). For glycogen synthase, the amidation site is bold framed with a dotted line (consensus: $x-G-[R K]-[R K])$.

Figure 2. Graphical representation of phylogenetic analysis of the glycogen phosphorylase (above) and synthase (below) enzymes. Sequence alignment was based on Clustal W (Thompson et al., 1994) and an unrooted distance base phylogenetic tree was constructed by PHYLIP (Felsenstein, 1993) using the unweighted-pair group method with arithmetic means (UPGMA). One thousand bootstrap trials were run using the Seqboot program from the PHYLIP package. Number at each node represents the percentage values given by bootstrap analysis. Genbank Accession $\mathrm{N}^{\circ}$ of glycogen phosphorylase sequences are: Giardia

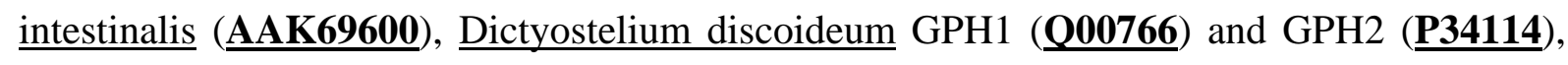
Caenorhabditis elegans (Q9N5U1), Drosophilae melanogaster (Q9XTL9), PHS1 Gallus

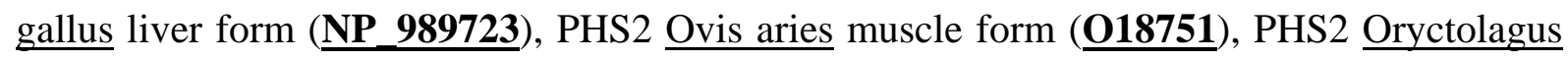

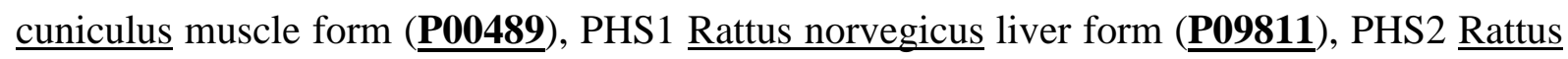

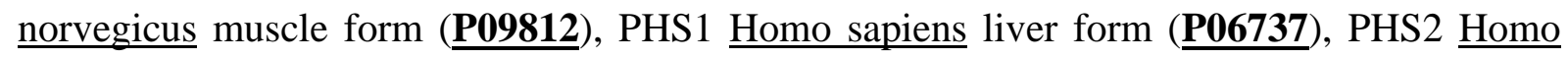

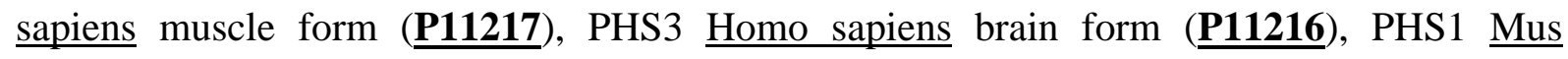

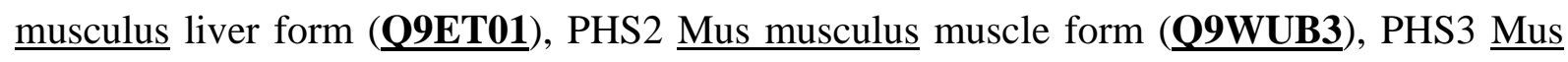
$\underline{\text { musculus brain form (Q8CI94)}) . ~ G e n b a n k ~ A c c e s s i o n ~} \mathrm{~N}^{\circ}$ of glycogen synthase sequences are: 
Giardia lamblia (EAA42246), Caenorhabditis elegans (Q942D9), Drosophilae melanogaster

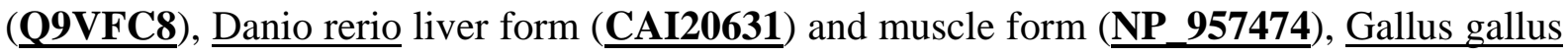
liver form ( $\underline{\mathbf{X P} \text { 416432)}}$, Oryctolagus cuniculus muscle form ( $\underline{\mathbf{P 1 3 8 3 4}})$, $\underline{\text { Rattus norvegicus }}$ liver form ( $\underline{\text { NP 037221) }}$ ) and muscle form ( $\underline{\text { XP_341859)}}$, Homo sapiens liver form (P_068776) and muscle form (P_002094), $\underline{\text { Mus musculus }}$ liver form (ㅍ663547),

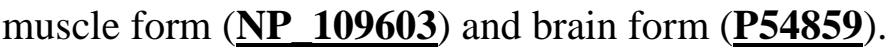

Figure 3. Ratio of glycogen synthase $\left(\mathrm{R}_{\mathrm{GS}}\right)$ and glycogen phosphorylase $\left(\mathrm{R}_{\mathrm{GP}}\right)$ transcripts relative to elongation factor I transcript in six oyster tissues in October and May, respectively. Data represent mean values for 15 oysters per tissue and are expressed as means \pm standard deviation. Multiple comparisons were made using a t-distribution test at the $5 \%$ level and homogenous groups share alphabetic letters.

Figure 4. Ratio of glycogen synthase $\left(R_{G S}\right)$ and glycogen phosphorylase $\left(R_{G P}\right)$ transcripts relative to elongation factor I transcripts in labial palps (black bar) and gonad (white bar) during experimental conditioning from March to January. Glycogen (mg glycogen /g wet weight of whole animal) levels estimated for tissues are represented by a curve. Data represent mean values for 15 oysters per sample and are expressed as means \pm standard deviation. 
Figure 1 :

Glycogen phosphorylase

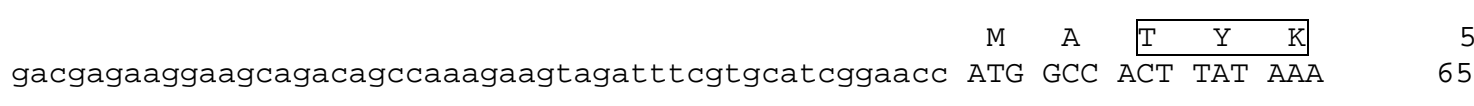
\begin{tabular}{lllllllllllllllllll}
$P$ & $T$ & $T$ & $D$ & $H$ & $E$ & $K$ & $R$ & $K$ & $Q$ & $I$ & $S$ & $I$ & $R$ & $G$ & $I$ & $A$ & $P$ & \\
\hline
\end{tabular}

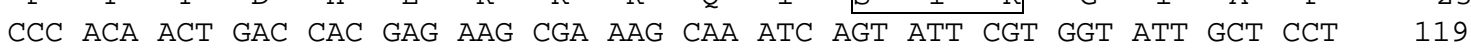

$\begin{array}{lllllllllllllllllll}V & E & N & V & V & E & F & K & K & A & F & N & R & H & L & H & Y & T & \end{array}$ GTG GAA AAT GTT GTC GAA TTC AAA AAG GCT TTT AAT CGC CAT TTG CAT TAC ACG 173

$\begin{array}{lllllllllllllllllllll}I & V & K & D & R & N & V & A & T & P & R & D & Y & Y & L & S & L & A & 59\end{array}$ ATT GTG AAA GAT AGA AAT GTG GCG ACA CCG CGA GAC TAC TAC CTC TCT CTT GCC 227

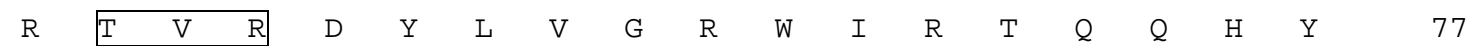
CGC ACC GTG CGA GAC TAT TTG GTG GGG CGT TGG ATC CGT ACC CAG CAG CAT TAC 281

$\begin{array}{lllllllllllllllllll}Y & E & K & D & P & K & R & V & Y & Y & L & S & L & E & F & Y & M & G & 95\end{array}$ TAT GAG AAG GAC CCA AAG AGA GTG TAC TAT CTG TCC CTG GAG TTT TAC ATG GGC 335

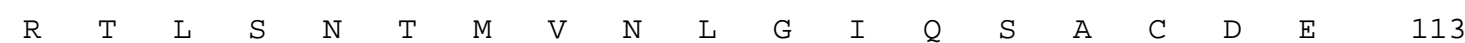
AGG ACC CTG TCC AAC ACC ATG GTG AAC CTG GGC ATT CAG AGC GCC TGC GAT GAG 389

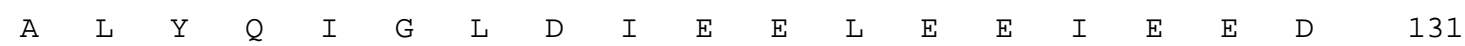
GCC CTC TAT CAG ATT GGC CTT GAC ATT GAG GAG TTG GAG GAG ATT GAG GAG GAT 443

$\begin{array}{lllllllllllllllllll}\text { A } & G & \text { L } & G & N & G & G & \text { L } & G & R & \text { L } & \text { A } & \text { A } & \text { C } & F & \text { L } & \text { D } & \text { S } & 149\end{array}$ GCT GGT CTG GGT AAT GGA GGA CTG GGT CGG CTG GCA GCC TGC TTC CTT GAC TCC 497

$\begin{array}{lllllllllllllllllll}M & \text { A } & \text { T } & \text { L } & \text { G } & \text { L } & \text { A } & \text { A } & \text { Y } & \text { G } & \text { Y } & \text { G } & \text { I } & \text { R } & \text { Y } & \text { D } & \text { Y } & \text { G } & 167\end{array}$ ATG GCA ACG CTC GGA CTG GCA GCA TAT GGA TAT GGT ATC AGA TAC GAC TAT GGA 551

$\begin{array}{lllllllllllllllllll}I & F & A & Q & K & I & E & D & G & W & Q & V & E & E & P & D & E & W & 185\end{array}$ ATC TTT GCC CAG AAA ATT GAA GAT GGT TGG CAG GTT GAG GAA CCT GAT GAG TGG 605

$\begin{array}{lllllllllllllllllll}L & R & Y & G & N & P & W & E & K & S & R & P & E & Y & V & L & P & V & 203\end{array}$ CTG AGA TAT GGA AAT CCA TGG GAG AAG TCG AGA CCA GAG TAC GTA CTA CCG GTC 659

$\begin{array}{lllllllllllllllllll}N & F & Y & G & R & T & E & D & T & G & S & G & V & K & W & V & D & T & 221\end{array}$

AAC TTC TAT GGA CGG ACA GAG GAC ACT GGC TCG GGG GTC AAG TGG GTG GAC ACT 713

$\begin{array}{lllllllllllllllllll}Q & V & V & F & A & M & P & F & D & S & P & I & P & G & Y & G & N & N & 239\end{array}$ CAG GTT GTG TTT GCG ATG CCC TTT GAC AGT CCT ATA CCA GGG TAC GGC AAC AAC 767

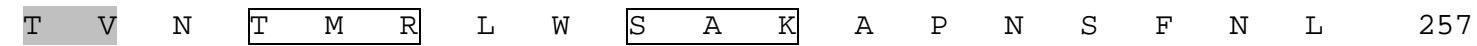
ACT GTC AAC ACC ATG CGT CTG TGG TCA GCT AAA GCT CCC AAC AGC TTC AAT CTG 821

$\begin{array}{lllllllllllllllllll}\text { H } & \text { F } & \text { F } & \text { N } & \text { N } & \text { G } & \text { E } & \text { Y } & \text { I } & \text { N } & \text { A } & \text { V } & \text { C } & \text { D } & \text { R } & \text { N } & \text { Q } & \text { A } & 275\end{array}$ CAC TTC TTC AAC AAT GGC GAG TAT ATC AAT GCT GTC TGT GAC AGA AAC CAG GCG 875

$\begin{array}{llllllllllllllllllll}\text { E } & N & \text { I } & \text { S } & R & V & \text { L } & \text { Y } & \text { P } & \text { N } & \text { D } & \text { N } & \text { F } & \text { F } & \text { S } & \text { G } & \text { K } & \text { E } & 293\end{array}$ GAA AAC ATC TCC AGA GTC CTC TAC CCC AAT GAT AAC TTC TTT TCT GGC AAA GAG 929

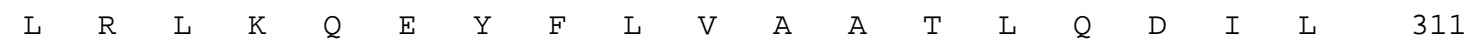
CTC CGC CTA AAG CAG GAG TAC TTC CTG GTA GCA GCC ACT CTC CAG GAC ATC CTC 983

$\begin{array}{lllllllllllllllllll}R & R & F & K & S & S & K & F & G & S & R & D & P & V & R & R & S & F & 329\end{array}$ AGg AGA TTC AAG TCA TCC AAG TTT GGT AGT CGG GAT CCG GTC CGC AGG TCC TTC 1037

$\begin{array}{lllllllllllllllllll}E & S & F & P & D & K & V & A & I & Q & L & N & D & T & H & P & S & M & 347\end{array}$ GAG TCG TTT CCA GAC AAG GTG GCC ATT CAG CTG AAT GAT ACC CAC CCG TCC ATG 1091

$\begin{array}{lllllllllllllllllll}A & I & P & E & L & L & R & I & F & V & D & V & E & G & L & P & W & D & 365\end{array}$ GCT ATC CCG GAG TTA CTG AGg ATC TTT GTG GAC GTT GAA GGA CTC CCA TGG GAC 1145 


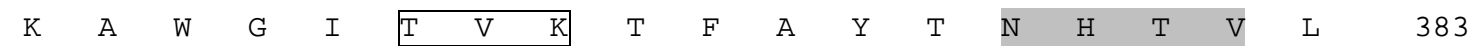
AAG GCC TGG GGA ATC ACG GTG AAG ACG TTC GCC TAC ACG AAC CAC ACA GTC CTC 1199

$\begin{array}{lllllllllllllllllllllllllll}P & E & A & L & E & R & W & P & V & S & M & L & E & K & I & L & P & R & 401\end{array}$ CCC GAG GCC TTG GAG AGG TGG CCG GTG TCC ATG CTG GAG AAG ATC CTT CCC CGC 1253

\begin{tabular}{lllllllllllllllllll}
$\mathrm{H}$ & $\mathrm{L}$ & $\mathrm{Q}$ & $\mathrm{I}$ & $\mathrm{I}$ & $\mathrm{Y}$ & $\mathrm{L}$ & $\mathrm{I}$ & $\mathrm{N}$ & $\mathrm{H}$ & $\mathrm{N}$ & $\mathrm{F}$ & $\mathrm{L}$ & $\mathrm{Q}$ & $\mathrm{E}$ & $\mathrm{V}$ & $\mathrm{A}$ & $\mathrm{K}$ & \\
\hline
\end{tabular} CAC CTG CAG ATT ATC TAC CTG ATT AAC CAC AAC TTC CTC CAG GAA GTA GCA AAA 1307

$\begin{array}{llllllllllllllllllllll}K & Y & P & G & D & A & G & R & M & R & R & M & S & I & V & E & E & D & & 437\end{array}$ AAA TAT CCA GGT GAT GCA GGC AGA ATG CGA CGA ATG TCC ATT GTA GAG GAG GAT 1361

$\begin{array}{lllllllllllllllllllll}G & E & K & R & I & N & M & A & Y & \text { L } & \text { S } & \text { I } & \text { V } & \text { G } & \text { S } & \text { H } & \text { A } & \text { V } & 455\end{array}$ GGA GAG AAG AGG ATC AAT ATG GCG TAT CTC AGC ATC GTC GGC TCG CAC GCT GTC 1415

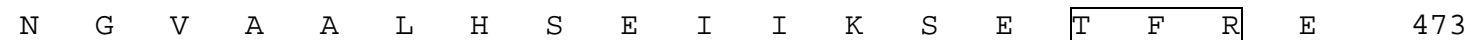
AAT GGA GTG GCA GCG TTA CAC TCA GAA ATC ATC AAG AGC GAA ACG TTC CGT GAG 1469

$\begin{array}{lllllllllllllllllllll}F & Y & E & M & Y & P & E & R & F & Q & N & K & T & N & G & I & T & P & 491\end{array}$ TTT TAC GAG ATG TAT CCA GAG CGC TTC CAA AAC AAA ACA AAC GGG ATC ACA CCA 1523

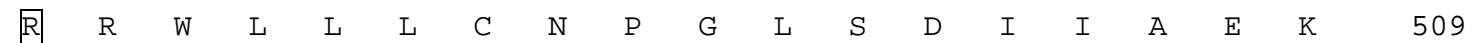
CGT CGT TGG TTG TTA CTG TGC AAT CCT GGA CTG TCT GAC ATT ATC GCA GAG AAA 1577

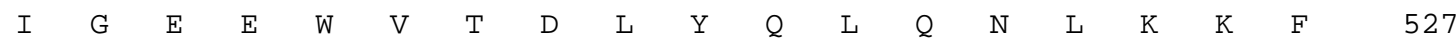
ATC GGG GAG GAA TGG GTC ACA GAC TTG TAC CAA CTA CAG AAT CTC AAA AAG TTT 1631

$\begin{array}{lllllllllllllllllll}A & D & D & E & N & F & L & R & N & I & I & K & V & K & 0 & E & N & K & 545\end{array}$ GCT GAT GAT GAA AAC TTC CTG AGG AAC ATC ATC AAA GTC AAA CAG GAA AAC AAA 1685

$\begin{array}{lllllllllllllllllllllllllllll}M & K & \text { L } & \text { A } & \text { E } & \text { Y } & \text { I } & \text { Q } & \text { E } & \text { N } & \text { Y } & \text { N } & \text { I } & \text { K } & \text { V } & \text { N } & \text { T } & \text { S } & 563\end{array}$ ATG AAG TTG GCT GAG TAC ATC CAG GAG AAC TAC AAC ATC AAG GTC AAC ACG TCC 1739

$\begin{array}{llllllllllllllllllllllll}\mathrm{S} & \mathrm{I} & \mathrm{F} & \mathrm{D} & \mathrm{I} & \mathrm{H} & \mathrm{V} & \mathrm{K} & \mathrm{R} & \mathrm{I} & \mathrm{H} & \mathrm{E} & \mathrm{Y} & \mathrm{K} & \mathrm{R} & \mathrm{Q} & \mathrm{L} & \mathrm{L} & & 581\end{array}$ TCC ATC TTT GAC ATC CAT GTC AAG CGG ATC CAC GAG TAC AAG AGA CAG CTG CTC 1793

\begin{tabular}{lllllllllllllllllll}
$\mathrm{N}$ & $\mathrm{C}$ & $\mathrm{F}$ & $\mathrm{H}$ & $\mathrm{I}$ & $\mathrm{I}$ & $\mathrm{T}$ & $\mathrm{L}$ & $\mathrm{Y}$ & $\mathrm{N}$ & $\mathrm{R}$ & $\mathrm{L}$ & $\mathrm{K}$ & $\mathrm{R}$ & $\mathrm{D}$ & $\mathrm{P}$ & $\mathrm{N}$ & 0 & \\
\hline
\end{tabular} AAT TGC TTC CAC ATC ATC ACG CTC TAC AAC CGC CTC AAG CGT GAC CCA AAC CAG 1847

$\begin{array}{lllllllllllllllllll}A & F & V & P & R & T & I & M & V & G & G & K & A & A & P & G & Y & H & 617\end{array}$ GCC TTT GTT CCC AGG ACT ATC ATG GTC GGA GGA AAG GCA GCT CCT GGC TAT CAC 1901

$\begin{array}{lllllllllllllllllll}\text { M } & \text { A } & \text { K } & \text { L } & \text { I } & \text { I } & \text { K } & \text { L } & \text { I } & \text { N } & \text { S } & \text { V } & \text { A } & \text { K } & \text { V } & \text { I } & \text { N } & \text { N } & 635\end{array}$ ATG GCC AAA CTG ATC ATC AAG CTG ATC AAC AGT GTA GCC AAG GTC ATC AAC AAC 1955

$\begin{array}{llllllllllllllllllll}D & P & I & I & G & D & R & L & K & V & V & Y & L & E & N & Y & R & V & 653\end{array}$ GAT CCA ATC ATC GGG GAC CGT CTC AAG GTG GTG TAT CTG GAG AAC TAC CGT GTC 2009

$\begin{array}{lllllllllllllllllll}\text { S } & \text { L } & \text { A } & \text { E } & \text { K } & \text { I } & \text { I } & \text { P } & \text { A } & \text { A } & \text { D } & \text { L } & \text { S } & \text { E } & \text { Q } & \text { I } & \text { S } & \text { T } & 671\end{array}$ TCG CTG GCT GAG AAG ATC ATT CCG GCA GCT GAC CTC AGC GAA CAG ATC TCG ACA 2063

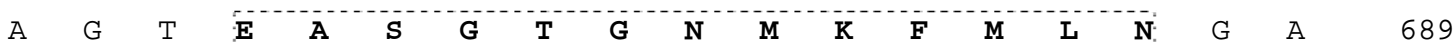
GCA GGA ACC GAG GCT TCT GGA ACA GGA AAC ATG AAG TTC ATG TTG AAC GGG GCA 2117

$\begin{array}{lllllllllllllllllll}\mathrm{L} & \mathrm{T} & \mathrm{I} & \mathrm{G} & \mathrm{T} & \mathrm{L} & \mathrm{D} & \mathrm{G} & \mathrm{A} & \mathrm{N} & \mathrm{V} & \mathrm{E} & \mathrm{M} & \mathrm{R} & \mathrm{E} & \mathrm{E} & \mathrm{M} & \mathrm{G} & 707\end{array}$ CTG ACT ATC GGA ACT CTG GAC GGT GCT AAT GTA GAG ATG AGA GAG GAG ATG GGG 2171

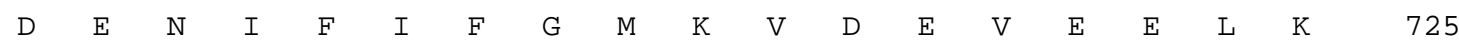
GAT GAA AAT ATC TTT ATC TTT GGA ATG AAG GTT GAT GAA GTA GAG GAA CTG AAG 2225

$\begin{array}{lllllllllllllllllll}\mathrm{R} & \mathrm{S} & \mathrm{G} & \mathrm{Y} & \mathrm{H} & \mathrm{P} & \mathrm{Q} & \mathrm{E} & \mathrm{Y} & \mathrm{Y} & \mathrm{E} & \mathrm{R} & \mathrm{N} & \mathrm{T} & \mathrm{D} & \mathrm{L} & \mathrm{K} & \mathrm{Q} & 743\end{array}$ CGC AGT GGG TAC CAC CCA CAA GAA TAC TAC GAG CGT AAC ACG GAC TTA AAG CAG 2279

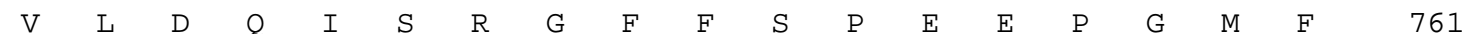
GTG CTT GAC CAG ATC TCA AGG GGC TTC TTC TCT CCC GAG GAG CCC GGC ATG TTC 2333

$\begin{array}{llllllllllllllllllllllllllll}T & D & I & Y & N & S & V & M & Y & N & D & R & F & X & P & S & K & D\end{array}$

779 
ACT GAT ATA TAC AAC TCT GTG ATG TAC AAC GAC AGG TTC TNG CCT TCT AAA GAT

$\begin{array}{lllllllllllllllllllll}\text { Y } & E & D & Y & I & K & C & Q & D & S & V & S & E & V & F & K & D & P & 797\end{array}$

TAT GAA GAT TAC ATC AAG TGC CAA GAC AGC GTC AGT GAA GTA TTC AAG GAT CCT 2441

$\begin{array}{llllllllllllllllllllllllllll}\mathrm{L} & \mathrm{Q} & \mathrm{W} & \mathrm{A} & \mathrm{K} & \mathrm{M} & \mathrm{C} & \mathrm{V} & \mathrm{L} & \mathrm{N} & \mathrm{I} & \mathrm{A} & \mathrm{S} & \mathrm{S} & \mathrm{V} & \mathrm{N} & \mathrm{F} & \mathrm{Q} & & 815\end{array}$

CTG CAA TGG GCC AAG ATG TGT GTC CTC AAC ATT GCA TCG TCG GTA AAT TTC CAG 2495

$\begin{array}{llllllllllllllllllllllllllll}P & T & E & Q & F & L & N & M & A & R & D & I & W & G & V & E & P & N & 833\end{array}$ CCG ACA GAA CAA TTT CTG AAT ATG GCA AGG GAC ATC TGG GGG GTG GAA CCC AAT 2549

$\begin{array}{lllllllllllllllllll}D & I & K & L & P & P & P & H & E & G & L & D & S & M & D & S & K & P & 851\end{array}$ GAT ATT AAG CTG CCG CCC CCA CAC GAG GGC CTA GAC TCA ATG GAT AGC AAA CCA 2603

$\begin{array}{lllllll}\mathrm{P} & \mathrm{Q} & \mathrm{K} & \mathrm{K} & * & 856\end{array}$

CCA CAG AAG AAA TGA gatctcagctgatagccactagaaacaatataacttttaaactttctgttg 2669

ttgctttgttgtggaatttattaacataggtcttatattaaagtttagcaatattacatgtaactggatgag 2741

gagaattgcagtagagattgacatactggtgttttagttgaagtgaaattgttgtcaggccattggacatac 2813

tcagctctgtggtagcatcacattgtaagcatcagcttgtaattaatatttggctggtctgtagagcatttg 2885

acttgtcctggtctaagcattttagtgcttttattgatgtgtcgttatgtgtgtaaatcaaactatggtat 2957

taaacagtttcattcaaaatctatataaaatttaagaaaatttgaaaaaaaaaaaaaaaa

3018

Glycogen synthase

$\begin{array}{lllllllllll}M & R & R & R & N & S & F & Y & R & & 9\end{array}$

tcggcacgaggctgagacagtgaaaattatggct ATG AGA AGA CGA AAC AGT TTT TAC AGA 61

$\begin{array}{llllllllllllllllllllll}S & F & K & D & A & C & P & E & F & E & E & M & L & M & D & R & G & A & & 27\end{array}$ AGT TTT AAA GAT GCA TGT CCG GAA TTT GAA GAG ATG CTT ATG GAC AGA GGG GCC 115

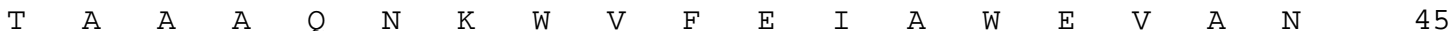
ACT GCA GCT GCA CAA AAC AAA TGG GTG TTT GAA ATC GCC TGG GAA GTA GCA AAT 169

\begin{tabular}{lllllllllllllllllll}
$K$ & $V$ & $G$ & $G$ & $I$ & $Y$ & $T$ & $V$ & $I$ & $K$ & $S$ & $K$ & $A$ & $P$ & $V$ & $S$ & $V$ & $A$ & \\
\hline
\end{tabular} AAA GTT GGT GGT ATC TAC ACT GTC ATC AAG TCC AAG GCC CCG GTC AGT GTA GCT 223

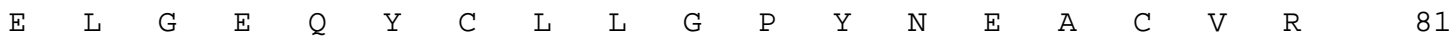
GAG TTA GGA GAA CAG TAC TGT CTG CTG GGT CCC TAT AAC GAG GCA TGT GTC AGA 277

$\begin{array}{llllllllllllllllllllllll}T & \mathrm{E} & \mathrm{V} & \mathrm{E} & \mathrm{I} & \mathrm{L} & \mathrm{E} & \mathrm{P} & \mathrm{S} & \mathrm{H} & \mathrm{Y} & \mathrm{V} & \mathrm{Y} & \mathrm{R} & \mathrm{Q} & \mathrm{T} & \mathrm{L} & \mathrm{Q} & & 99\end{array}$ ACG GAG GTG GAG ATC CTG GAG CCC TCC CAC TAT GTC TAC AGA CAG ACG CTA CAG 331

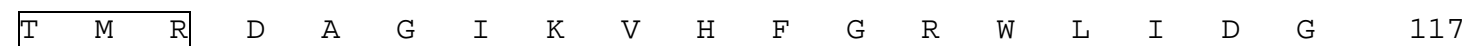
ACC ATG AGG GAC GCA GGT ATC AAG GTT CAT TTT GGT CGC TGG CTG ATA GAC GGA 385

$\begin{array}{llllllllllllllllllllllllll}Y & P & K & V & I & L & F & D & I & G & S & A & A & W & K & L & D & E & & 135\end{array}$ TAT CCT AAA GTC ATT TTG TTT GAC ATC GGA TCT GCT GCT TGG AAG CTG GAT GAA 439

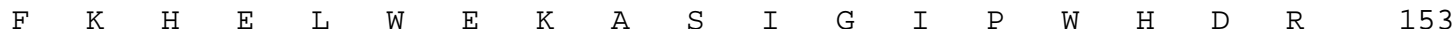

TTC AAA CAT GAG CTG TGG GAG AAA GCC AGC ATA GGA ATC CCC TGG CAC GAC CGC 493

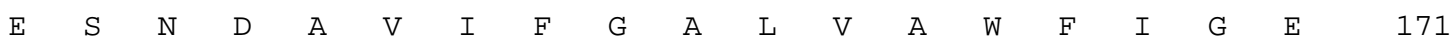

GAG TCG AAC GAC GCC GTC ATA TTC GGG GCT CTA GTA GCC TGG TTT ATT GGT GAG 547

$\begin{array}{llllllllllllllllllllllllll}F & R & K & N & L & T & D & Q & P & I & V & V & T & H & F & H & E & W & 189\end{array}$ TTT CGG AAG AAT CTG ACT GAT CAG CCG ATT GTA GTG ACC CAC TTT CAC GAG TGG 601

$\begin{array}{lllllllllllllllllll}\mathrm{L} & \mathrm{A} & \mathrm{G} & \mathrm{A} & \mathrm{G} & \mathrm{L} & \mathrm{M} & \mathrm{D} & \mathrm{L} & \mathrm{R} & \mathrm{T} & \mathrm{R} & \mathrm{K} & \mathrm{V} & \mathrm{D} & \mathrm{C} & \mathrm{I} & \mathrm{T} & 207\end{array}$

TTG GCT GGG GCG GGG CTG ATG GAC CTG CGG ACC AGG AAG GTC GAC TGC ATC ACC 655 
$\begin{array}{lllllllllllllllllll}\mathrm{I} & \mathrm{F} & \mathrm{T} & \mathrm{T} & \mathrm{H} & \mathrm{A} & \mathrm{T} & \mathrm{L} & \mathrm{L} & \mathrm{G} & \mathrm{R} & \mathrm{Y} & \mathrm{L} & \mathrm{C} & \mathrm{A} & \mathrm{G} & \mathrm{S} & \mathrm{S} & 225\end{array}$ ATC TTC ACG ACT CAC GCC ACA CTG CTG GGG AGA TAC CTG TGT GCT GGC AGC TCA 709 $\begin{array}{lllllllllllllllllllllllllll}D & F & Y & N & N & I & D & K & Y & N & \text { L } & \text { V } & \text { K } & \text { E } & \text { A } & \text { G } & \text { D } & \text { R } & & 243\end{array}$ GAC TTC TAC AAC AAT ATA GAC AAG TAT AAC TTA GTC AAG GAG GCC GGT GAC CGT 763

$\begin{array}{llllllllllllllllllll}Q & I & Y & H & C & Y & C & M & E & R & T & A & V & H & S & S & Q & V & & 261\end{array}$ CAG ATA TAC CAC TGT TAC TGC ATG GAG AGG ACC GCT GTC CAC TCT TCT CAG GTG 817

$\begin{array}{llllllllllllllllllllllll}F & I & S & V & S & E & I & T & E & V & E & A & E & H & L & L & K & R & 279\end{array}$ TTT ATC AGT GTG TCC GAG ATC ACT GAG GTG GAG GCA GAG CAC CTG CTC AAA CGg 871

$\begin{array}{lllllllllllllllllllllll}K & P & N & M & I & V & P & P & N & G & L & N & V & V & K & F & S & T & & 297\end{array}$ AAG CCC AAC ATG ATC GTC CCA CCT AAC GGA TTA AAT GTG GTC AAA TTT AGT ACC 925

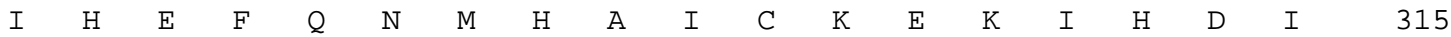
ATC CAT GAG TTC CAG AAT ATG CAT GCC ATC TGC AAG GAG AAG ATC CAC GAC ATC 979

$\begin{array}{llllllllllllllllllll}V & R & G & H & F & Y & G & H & Y & D & F & D & L & D & K & T & L & Y & & 333\end{array}$

GTC AGG GGA CAT TTT TAT GGG CAC TAT GAC TTT GAT CTG GAT AAG ACA CTA TAC 1033

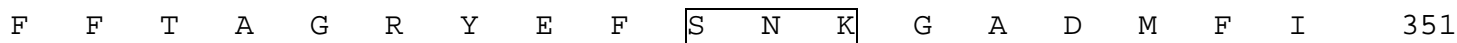
TTT TTC ACG GCT GGg AGA TAT GAG TTT TCC AAC AAA GGA GCG GAC ATG TTC ATA 1087

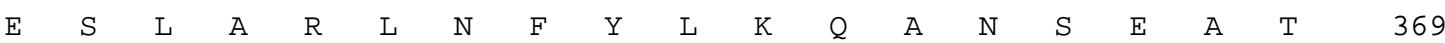
GAA TCA CTG GCA AGA CTA AAC TTT TAT CTC AAG CAA GCT AAC AGT GAG GCG ACA 1141

$\begin{array}{lllllllllllllllllll}\mathrm{V} & \mathrm{V} & \mathrm{A} & \mathrm{F} & \mathrm{L} & \mathrm{I} & \mathrm{F} & \mathrm{P} & \mathrm{T} & \mathrm{K} & \mathrm{T} & \mathrm{N} & \mathrm{N} & \mathrm{F} & \mathrm{N} & \mathrm{V} & \mathrm{E} & \mathrm{S} & 387\end{array}$ GTG GTG GCT TTC CTG ATC TTC CCC ACC AAG ACC AAC AAC TTC AAC GTG GAG TCC 1195

$\begin{array}{lllllllllllllllllll}\mathrm{L} & \mathrm{R} & \mathrm{G} & \mathrm{Q} & \mathrm{A} & \mathrm{I} & \mathrm{S} & \mathrm{K} & \mathrm{Q} & \mathrm{L} & \mathrm{K} & \mathrm{E} & \mathrm{T} & \mathrm{V} & \mathrm{H} & \mathrm{H} & \mathrm{V} & \mathrm{Q} & 405\end{array}$ CTG CGG GGC CAG GCC ATC TCC AAA CAG CTG AAG GAG ACC GTG CAC CAC GTA CAG 1249

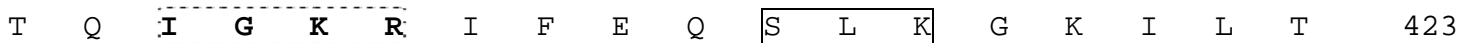
ACA CAG ATC GGC AAG AGg ATC TTT GAA CAG AGC CTG AAG GGC AAA ATT CTA ACT 1303

$\begin{array}{lllllllllllllllllllllll}G & D & E & I & L & E & Q & E & D & I & V & K & L & K & R & C & I & Y & & 441\end{array}$ GGA GAT GAA ATT CTG GAA CAA GAA GAT ATA GTG AAA CTT AAG AGG TGT ATC TAC 1357

$\begin{array}{lllllllllllllllllll}\mathrm{S} & \mathrm{A} & \mathrm{Q} & \mathrm{R} & \mathrm{N} & \mathrm{S} & \mathrm{L} & \mathrm{P} & \mathrm{P} & \mathrm{I} & \mathrm{C} & \mathrm{T} & \mathrm{H} & \mathrm{N} & \mathrm{V} & \mathrm{N} & \mathrm{E} & \mathrm{D} & 459\end{array}$ TCT GCT CAG AGA AAC AGC TTA CCT CCT ATA TGT ACG CAC AAT GTT AAT GAA GAC 1411

$\begin{array}{lllllllllllllllllll}\text { A } & \text { N } & \text { D } & \text { Q } & \text { I } & \text { L } & \text { N } & \text { A } & \text { L } & \text { R } & \text { R } & \text { C } & \text { Q } & \text { L } & \text { F } & \text { N } & \text { R } & \text { K } & 477\end{array}$ GCG AAC GAC CAA ATC CTT AAT GCC CTT CGA CGA TGT CAA CTT TTC AAC AGA AAA 1465

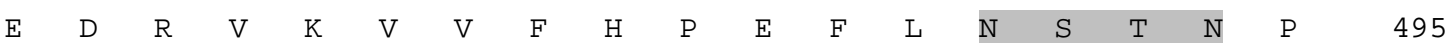
GAG GAC AGA GTG AAG GTT GTA TTT CAC CCC GAG TTC CTG AAC TCC ACC AAC CCT 1519

$\begin{array}{lllllllllllllllllllll}\mathrm{L} & \mathrm{F} & \mathrm{G} & \mathrm{L} & \mathrm{D} & \mathrm{Y} & \mathrm{E} & \mathrm{D} & \mathrm{F} & \mathrm{V} & \mathrm{R} & \mathrm{G} & \mathrm{C} & \mathrm{H} & \mathrm{L} & \mathrm{G} & \mathrm{V} & \mathrm{F} & 513\end{array}$ TTG TTT GGC CTT GAC TAC GAG GAC TTT GTC CGG GGC TGT CAC CTT GGG GTG TTC 1573

$\begin{array}{llllllllllllllllllllllll}A & S & Y & Y & E & P & W & G & Y & S & P & A & E & C & T & V & Y & G & 531\end{array}$ GCT TCG TAC TAC GAG CCC TGG GGC TAT TCA CCA GCT GAG TGC ACC GTG TAC GGG 1627

$\begin{array}{llllllllllllllllllllll}I & P & S & I & S & T & N & \text { L } & \text { S } & G & F & G & C & F & M & Q & E & H & & 549\end{array}$ ATC CCA AGT ATT TCC ACG AAC CTC TCA GGC TTC GGC TGT TTC ATG CAG GAA CAC 1681

$\begin{array}{lllllllllllllllllll}\mathrm{I} & \mathrm{N} & \mathrm{D} & \mathrm{P} & \mathrm{K} & \mathrm{S} & \mathrm{Y} & \mathrm{G} & \mathrm{L} & \mathrm{Y} & \mathrm{I} & \mathrm{V} & \mathrm{D} & \mathrm{R} & \mathrm{R} & \mathrm{Y} & \mathrm{K} & \mathrm{S} & 567\end{array}$ ATC AAT GAT CCC AAG TCC TAT GGA CTC TAT ATT GTA GAC CGC CGA TAT AAG AGT 1735

$\begin{array}{lllllllllllllllllllllllll}P & D & E & S & \text { I } & H & Q & \text { L } & \text { T } & \text { Q } & \text { Y } & \text { M } & \text { Y } & \text { D } & \text { F } & \text { T } & \text { C } & \text { L } & 585\end{array}$ CCA GAC GAA TCA ATC CAT CAG CTG ACT CAG TAT ATG TAT GAT TTC ACC TGT TTA 1789

$\begin{array}{lllllllllllllllllll}\mathrm{S} & \mathrm{R} & \mathrm{R} & \mathrm{Q} & \mathrm{R} & \mathrm{I} & \mathrm{I} & \mathrm{Q} & \mathrm{R} & \mathrm{N} & \mathrm{R} & \mathrm{T} & \mathrm{E} & \mathrm{R} & \mathrm{L} & \mathrm{S} & \mathrm{D} & \mathrm{L} & 603\end{array}$ TCC CGG CGA CAG CGT ATC ATT CAG AGA AAT CGT ACG GAG CGC CTC AGT GAC CTC 1843

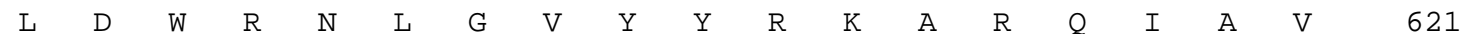
CTA GAC TGG AGG AAC CTG GGA GTG TAC TAC AGA AAA GCC CGC CAG ATT GCT GTA 1897 
$\begin{array}{lllllllllllllllllll}\text { A } & R & G & Y & P & D & \text { L } & \text { A } & \text { A } & \text { K } & \text { E } & \text { E } & \text { E } & \text { I } & \text { L } & \text { Q } & \text { E } & \text { K } & 639\end{array}$ GCC CGG GGA TAC CCT GAC CTT GCT GCC AAG GAG GAG GAG ATC CTA CAG GAA AAG 1951 $\begin{array}{lllllllllllllllllll}R & F & M & Y & P & R & P & A & S & E & P & S & S & P & S & A & S & R & \end{array}$ AGG TTC ATG TAC CCT CGG CCG GCC TCC GAA CCT TCC TCA CCC TCG GCC TCG CGC 2005 \begin{tabular}{lllllllllllllllllll}
$\mathrm{S}$ & $\mathrm{S}$ & $\mathrm{T}$ & $\mathrm{P}$ & $\mathrm{A}$ & $\mathrm{P}$ & $\mathrm{S}$ & $\mathrm{E}$ & $\mathrm{H}$ & $\mathrm{G}$ & $\mathrm{D}$ & $\mathrm{D}$ & $\mathrm{E}$ & $\mathrm{D}$ & $\mathrm{D}$ & $\mathrm{D}$ & $\mathrm{I}$ & $\mathrm{D}$ & \\
\hline
\end{tabular} AGC TCC ACC CCA GCC CCC TCG GAA CAT GGG GAC GAT GAA GAT GAC GAT ATC GAC 2059 $\begin{array}{llllllllllllllllllllll}E & D & E & E & N & A & E & M & S & S & N & P & E & S & D & M & P & M & 693\end{array}$ GAG GAT GAA GAG AAT GCG GAA ATG AGT TCT AAC CCA GAG TCC GAC ATG CCG ATG 2113 $\mathrm{F} \quad \mathrm{K}$ *

TTT AAG TGA tgaatcagaaggacatcccggtttattgttacatgttaaaggatttctatcagtttgta 2181

ggttaattacctggtgtattgagtagtgaggtgtttgctttataccacagaaaagctttatataatactgg 2253 agtgttggcgagtgcactcaaatgagttgacctcattttaacattttatttgctttcttctttatttct 2325 ctcttctagttagcaatcaaaatgtttcacaacatagtatgtcgttgtgaggtaaaaatttaacaaaaaaa 2397 aaaaaaaaaaa 2408 


\section{Figure 2:}

Glycogen phosphorylase

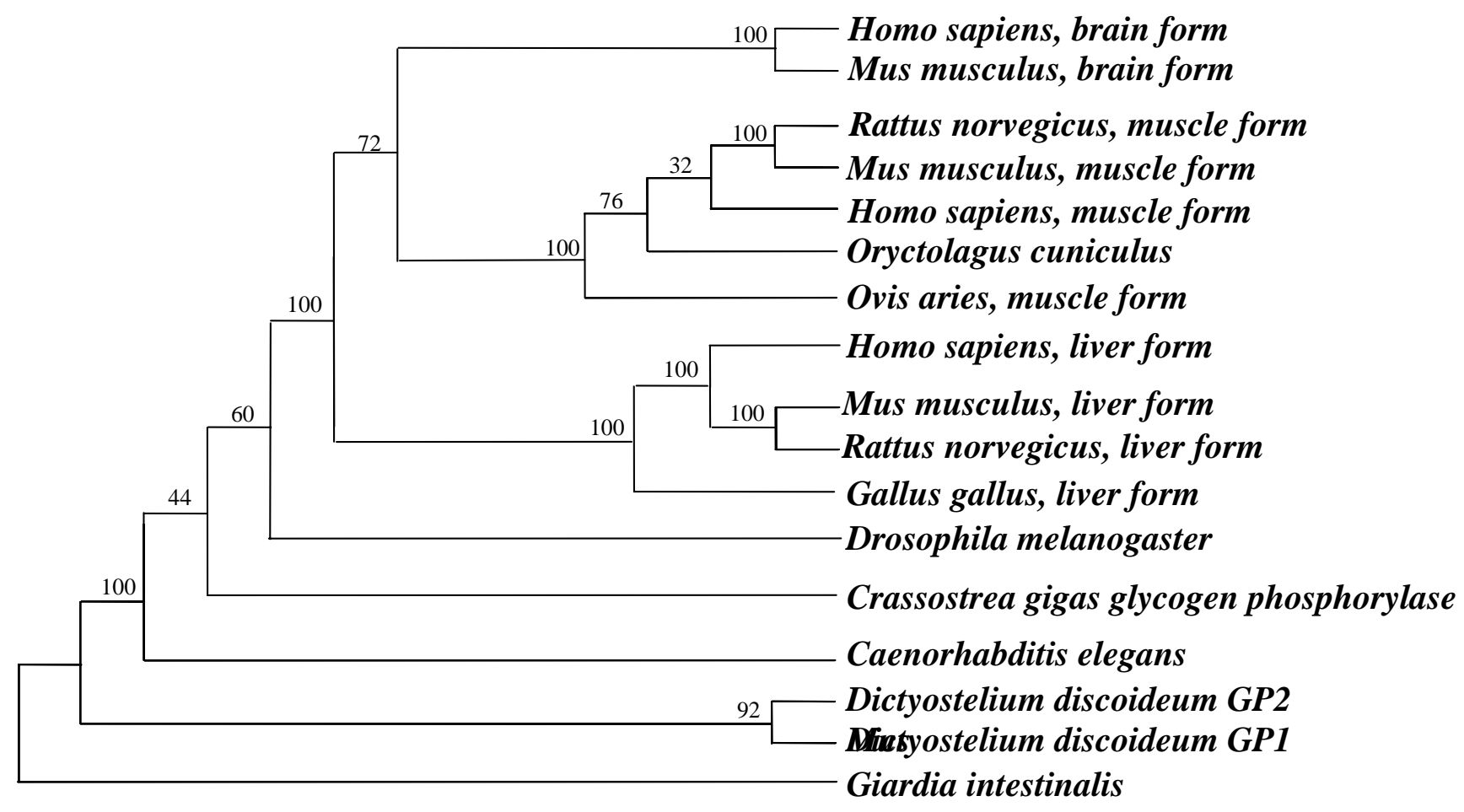

Glycogen synthase

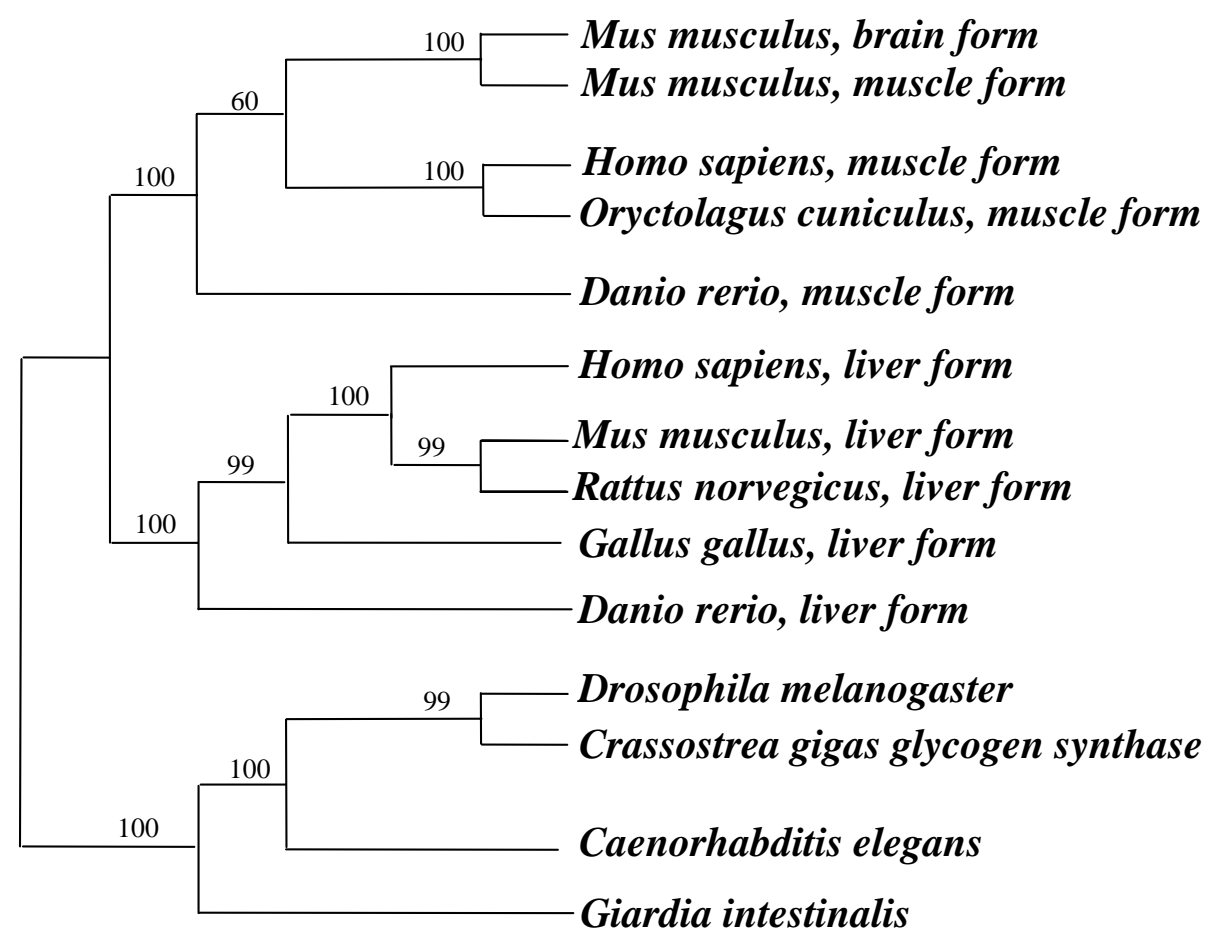


Figure 3:
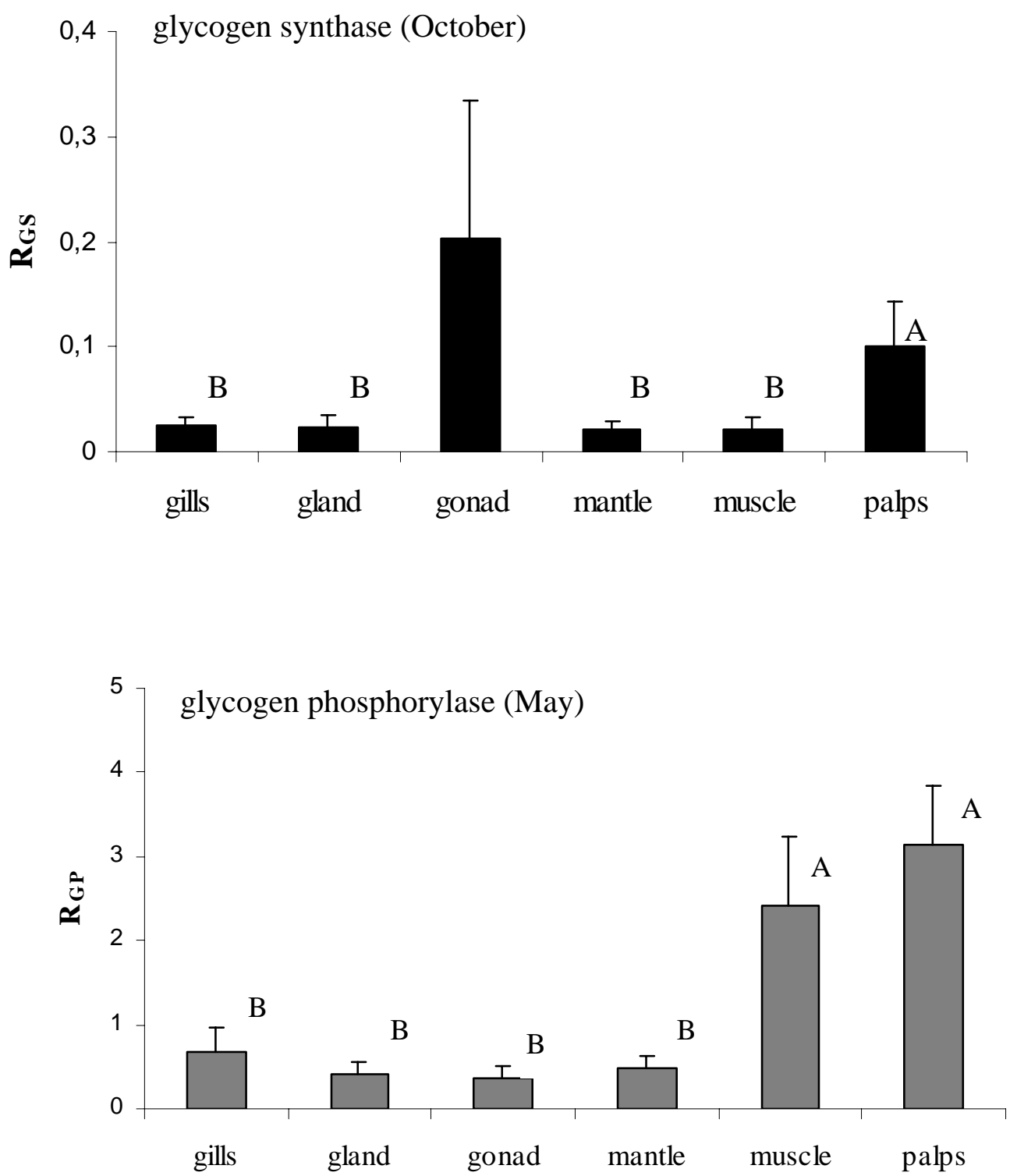
Figure 4:
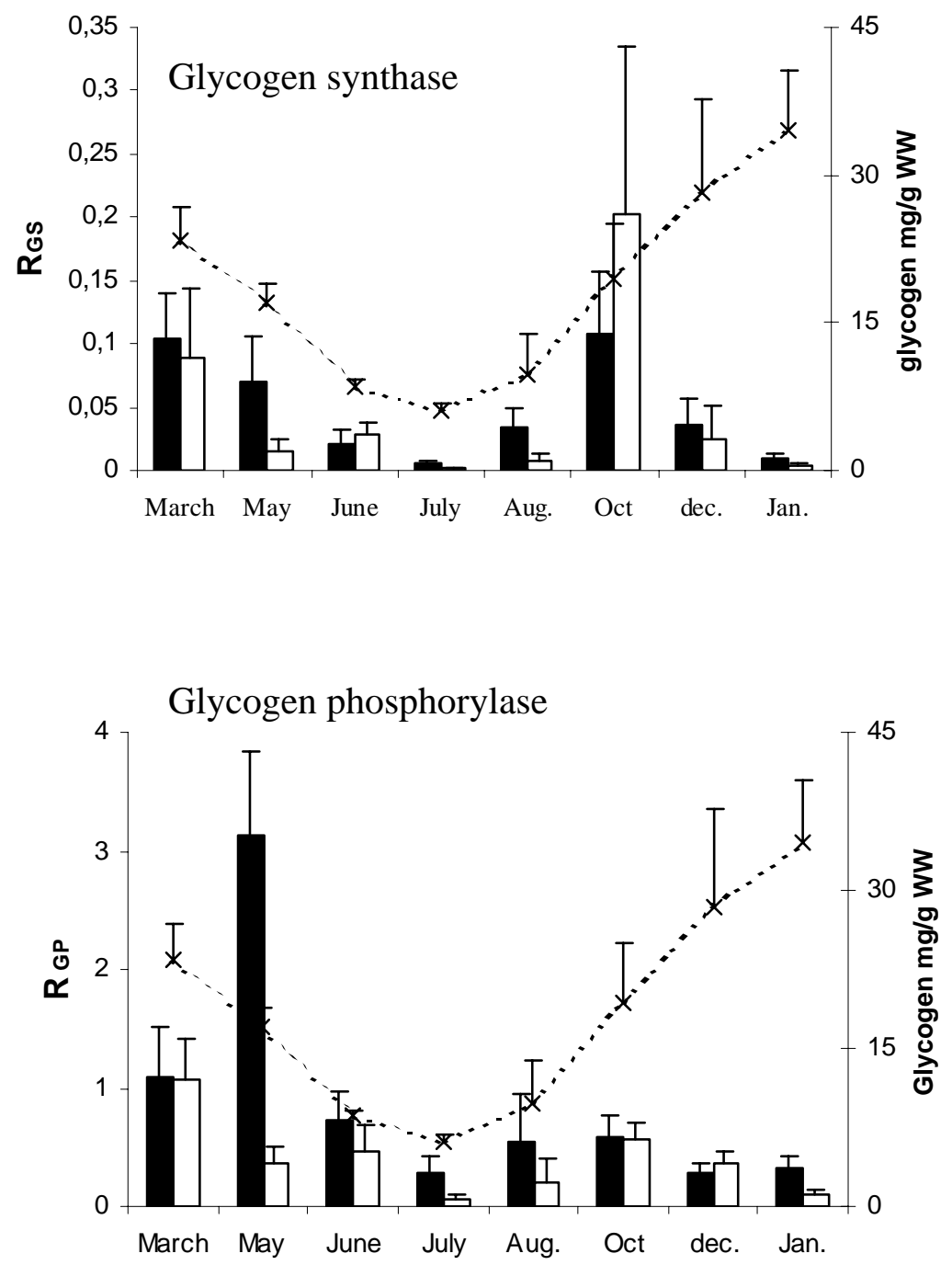